\title{
FOREIGN DIRECT INVESTMENT AND HUMAN DEVELOPMENT
}

\author{
Irina Orbes Cervantes
}

U5402781

A thesis submitted for the degree of

Master of Philosophy

Research School of Management

College of Business and Economics

The Australian National University

September 2017

(C) Copyright by Irina Orbes Cervantes 2017 


\section{DECLARATION OF ORIGINALITY}

I certify that this thesis does not incorporate without acknowledgement any material previously submitted for a degree or diploma in any university; and that to the best of my knowledge and belief it does not contain any material previously published or written by another person except where due reference is made in the text.

Signed: Irina Orbes Cervantes

On: $29 /$ Sept $/ 2017$ 


\section{ACKNOWLEDGEMENTS}

I would like to express the deepest appreciation to my supervisors who had the attitude and time to guide this thesis. Dr. Alex Eapen has continually supported me with enthusiasm, positivity and excitement. The completion of this thesis would have not been possible without his revisions and suggestions. I would also like to thank Dr. Andrew Bradly who has convincingly encouraged me through this process, his inputs and comments on this thesis had made this work much more meaningful.

A special thanks to Professor George Chen and Associate Professor Lin Cui for their valuable support and advices. They have guided my research career and also developed my research skills. I would also like to express my appreciation to Professor Byron Keating and the administrative staff of our school and college for their support and assistance in this period.

I would like to deeply thank my husband who has been the key pillar in my life, I am very grateful for his love, assistance and inspiration. I also appreciate all his guidance and encouragement to do my best and to overcome the challenges during my study. I am also very grateful to my beloved parents who have been my biggest supporters. They have always been there for me, encouraging me to grow and develop my skills as a professional but also as a person. This thesis would have not been possible without your support.

I would also like to thank my friends and colleagues for their emotional support which has made this study more enjoyable. Finally, thanks to the Government of Australia for the tuition fee scholarship. 


\section{TABLE OF CONTENTS}

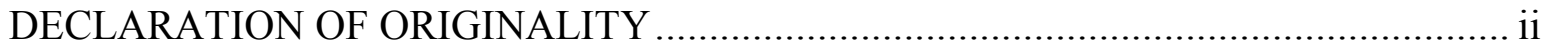

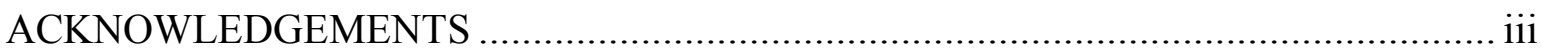

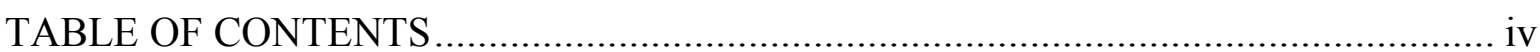

FOREIGN DIRECT INVESTMENT AND HUMAN DEVELOPMENT ........................... 1

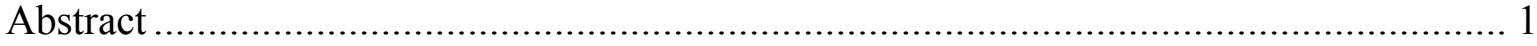

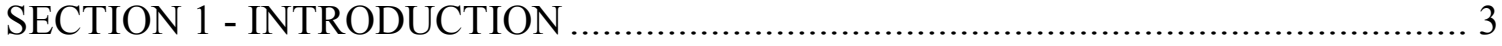

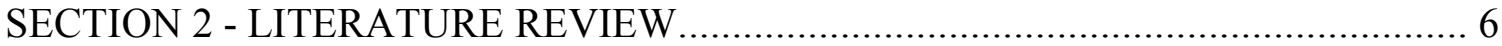

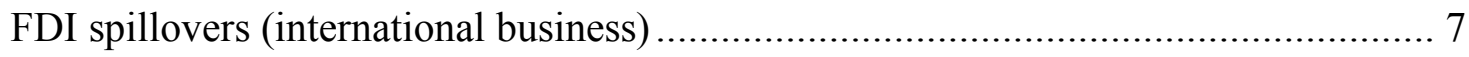

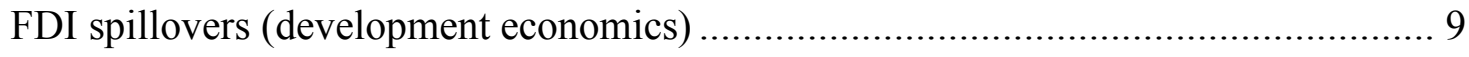

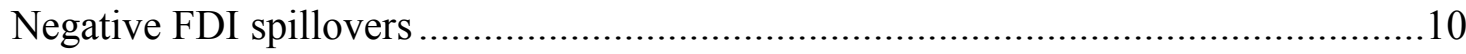

Human development ......................................................................................11

SECTION 3 - THEORY AND HYPOTHESES ……….............................................

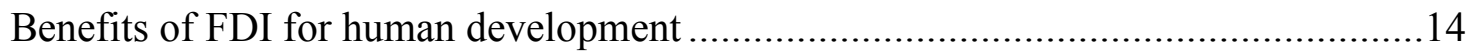

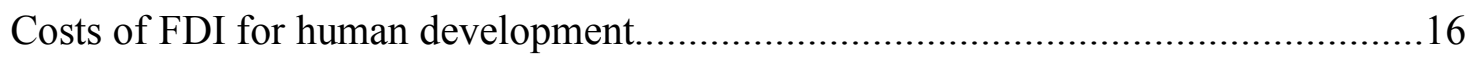

Moderating role of institutions: Business sophistication and transparency ..................19

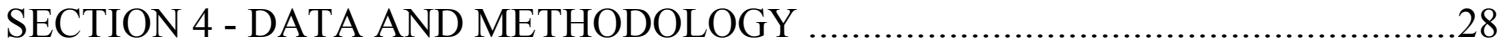

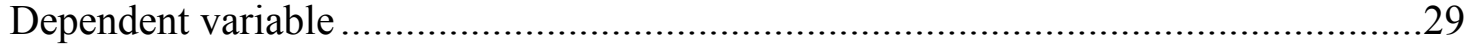

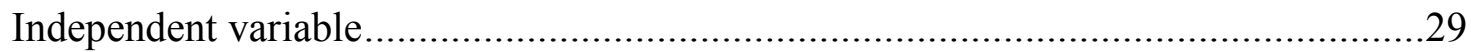

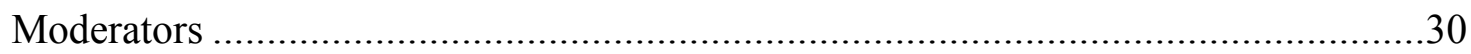

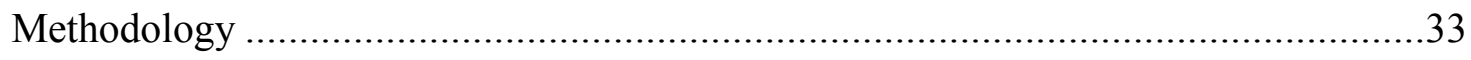

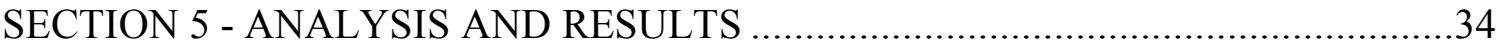

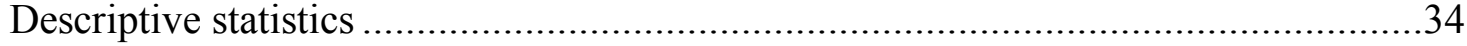

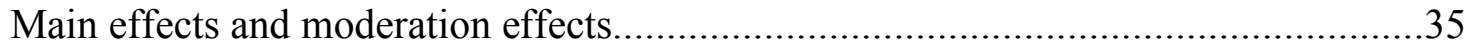

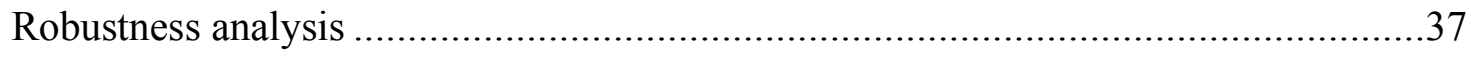

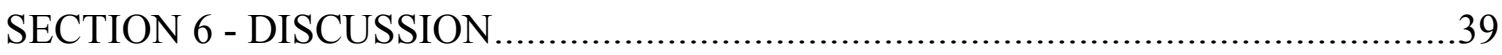

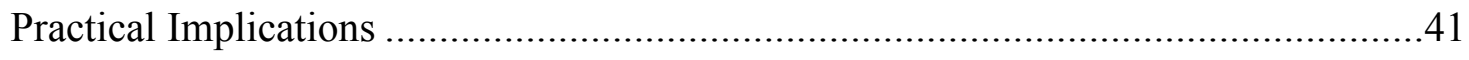

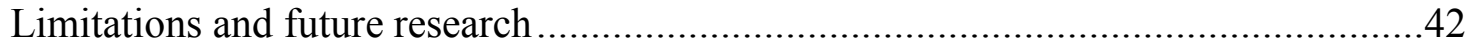




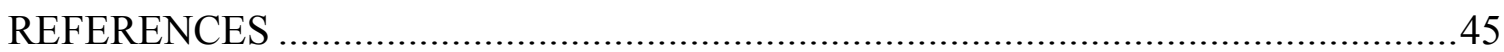

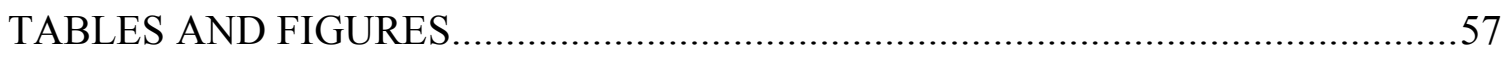

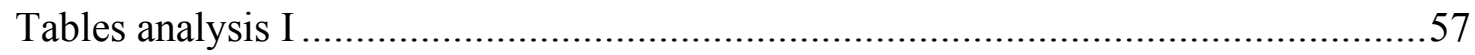

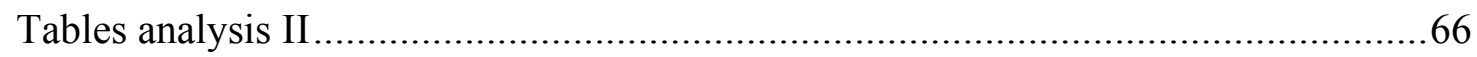

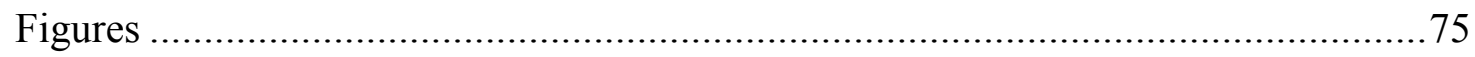

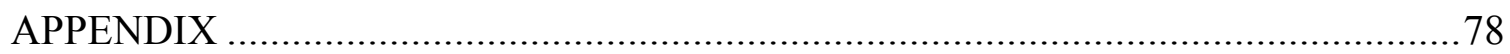

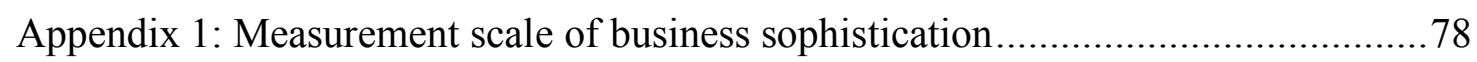

Appendix 2: List of the countries included on the sample .....................................80

Appendix 3: Moderation matrix - Business Sophistication and Transparency............82 



\title{
FOREIGN DIRECT INVESTMENT AND HUMAN DEVELOPMENT
}

\author{
Abstract \\ In this thesis, I examine the relationship between foreign direct investment (FDI) in a host \\ country and human development. Human development comprises the education, health, and \\ income opportunities available to people in a particular country. I assert that FDI can \\ potentially enhance human development through economic growth and higher income in a \\ host country. However, alongside these benefits, FDI can also have negative effects by \\ worsening a host country's income inequality. Given FDI's counteracting positive and \\ negative effects on human development, I propose that FDI's net effect on human \\ development takes the form of an inverted U-shaped relationship. \\ I further predict that a host country's institutional maturity, defined as the degree of \\ institutional development within a country, plays an important role in understanding which \\ national contexts strengthen or weaken this relationship. I contend that the inverted U- \\ shaped relationship between FDI and human development is moderated by a host country's \\ institutions, and assess this moderation with respect to two dimensions: business \\ sophistication and transparency. Business sophistication measures the extent to which a \\ country possesses supplier networks, technology production, and advanced business \\ practices (World Economic Forum, 2015). My results show that countries with low \\ business sophistication have a pronounced inverted U-shaped relationship between FDI and \\ human development, while countries with high business sophistication experience an
}


attenuated effect (flattened inverted U-shaped). Similarly, transparency measures publicsector employees and executives' accountability and performance, as well as civil society's access to information about public affairs (World Bank, 2016). My results show that economies with low transparency have a steeper inverted U-shaped relationship between FDI and human development; by contrast, economies with high transparency exhibit a flatter inverted U-shaped curve.

My study makes three core contributions to the field. First, it adds to development economics scholars' analysis of human development by proposing that income inequality is a key FDI cost. Therefore, while FDI can indeed enhance human development (as past studies have shown), it can also have a negative effect by worsening a host country's income inequality. Second, my study facilitates better knowledge of the relationship between FDI and human development by integrating the positive and negative effects of this relationship. Third, in line with studies that propose the contingent effects of FDI (Meyer \& Sinani, 2009), my study contributes to understanding how a host country's institutional maturity in the private and public sectors affects the strength of FDI's curvilinear effect on human development. 


\section{SECTION 1 - INTRODUCTION}

Foreign direct investment (FDI) is the financial lifeblood of globalization. Unsurprisingly, the study of FDI's effects on host locations has been a matter of high priority for international business researchers for more than four decades. Unfortunately, there has been considerable divergence in the conclusions these various studies have reached. Some (e.g., Blomström, 1986; Blomström \& Persson, 1983; Blomström \& Wolff, 1994; Globerman, 1979; Kokko, Tansini, \& Zejan, 1996) have found evidence for FDI's positive spillover effects on the productivity of domestic firms in host countries, while others have observed negative productivity spillover effects (Aitken \& Harrison, 1999). This research continues to expand, highlighting both FDI's benefits and costs for domestic firms (Driffield \& Love, 2007; Tian, 2007; Zhang, Li, Li, \& Zhou, 2010). In addition, meta-analytic studies have offered an overall summary of the relationship between inward FDI and productivity spillover for a host country's domestic firms (Gorg \& Strobl, 2001; Meyer \& Sinani, 2009).

Yet these "FDI spillover" studies collectively describe only a narrow sliver of the effect inward FDI has on host countries. Their focus is almost solely on FDI's productivity benefits (or costs) for domestic firms. The broader effects of FDI on human development in a host country, while unequivocally important, have received comparatively little attention. Human development comprises the education, health, and income opportunities available to people in a country (United Nations Development Programme [UNDP], 2015b). It is fundamental to human wellbeing, and constitutes the bedrock of freedom and opportunity for any human population (UNDP, 2015b). Further, according to recent accounts, over 70\% of poor people today live in inadequate human development conditions (Melamed \& Samman, 2013). However, despite the importance of human development for host country 
populations, international business literature has largely ignored how FDI affects human development in host countries.

Fortunately, in a separate strand of literature in the field of development economics, several studies have explored the link between FDI and human development. In general, they have found a positive association between the two (Arcelus, Sharma, \& Srinivasan, 2005; Lehnert, Benmamoun, \& Zhao, 2013; Reiter \& Steensma, 2010; Sharma \& Gani, 2004; Stiglitz, 2006). Some have also attempted to better understand the relevant mediators and moderators in the relationship between FDI and human development (Lehnert et al., 2013; Reiter \& Steensma, 2010). These studies have undoubtedly enhanced understanding of FDI's effects on human development, although they have also largely been one-sided, overlooking the potential cost of FDI on human development.

Thus, as a whole, current literature remains lacking in two respects. First, FDI spillover studies in international business literature must go beyond their narrow focus on how inward FDI affects domestic firms' productivity; the broader effects of FDI on human development in host countries is simply too important to ignore. Second, a more balanced perspective on the effects of FDI on human development is needed — one that takes into account both positive and negative effects.

My thesis attempts to meet these two needs (i) the effect of inward FDI on human development and (ii) the integrated outcome of both positive and negative effects of FDI. In doing so, I make three core arguments. First, I argue that a key cost of FDI for human development is income inequality (Basu \& Guariglia, 2007; Chintrakarn, Herzer, \& Nunnenkamp, 2012; Choi, 2006; Herzer, Hühne, \& Nunnenkamp, 2014; Pan-Long, 1995). While FDI can indeed enhance human development (as past studies in the field of 
development economics have shown) by improving host country's income and growth. It can also have a negative effect by distributing these benefits unevenly, worsening the host country's income inequality. Income inequality leads to unequal access to capabilities, and thus to uneven human development (Melamed \& Samman, 2013). Second, given FDI's counteracting positive and negative effects on human development, I propose that the net effect of these effects of FDI on host country's human development is curvilinear. I therefore predict that FDI enhances economic growth and high income in the host country (Borensztein, De Gregorio, \& Lee, 1998), and exerts a positive effect on human development. However, alongside these benefits, FDI also increases income inequality (Herzer et al., 2014); ultimately, these negative, income inequality-driven effects will outweigh FDI's initial positive benefits which result in an inverted U-shaped relationship. Third, in line with studies that propose FDI's contingent effects (Meyer \& Sinani, 2009) and highlight the importance to understand when these effects affect differently the host country. I suggest that the strength of FDI's curvilinear effect on human development depends on the host country's institutional maturity in the private and public sectors. I assess the quality of institutions in the private and public sectors with respect to two dimensions: business sophistication and transparency, respectively. Business sophistication refers to the extent of the host country's supplier networks, technology production, and advanced business practices (World Economic Forum, 2015). This dimension is likely to demonstrate whether a country has infrastructure and business system to support and channel multinational entities (MNEs) and their requirements which translates in countries that have strong, weak or absent private institutions. Transparency refers to the extent of public-sector executives and employees' accountability and reliability in terms of their 
activities and actions in the host country. This dimension is likely to demonstrate how well manage is the legal, business and public environment of the country which demonstrate the public business practices that shape and support the market for MNEs. I propose that the relationship between FDI and human development is most pronounced in countries with low business sophistication and transparency.

To test my hypothesis, I sourced and matched data from multiple sources. I obtained data on human development from the UNDP (2015a), and then matched this with data on inward FDI flows and stock from the United Nations Conference on Trade and Development (UNCTAD) (2016). I further matched my dataset with data on business sophistication and transparency from the World Economic Forum (2016) and the World Bank's (2016) World Development Indicators database, respectively. Consistent with my expectations, I found that inward FDI has an inverted U-shaped relationship with human development in the host country. In addition, I found that countries with low business sophistication and transparency exhibit a more pronounced curvilinear relationship than those with high business sophistication and transparency.

This thesis is organized into six sections. Following this introduction, in section two, I review the relevant literature. In section three, I explore how FDI affects human development, and formulate my hypotheses. In section four, I describe the data and methodology used. Section five provides my empirical results, and in section six, I conclude and discuss the contributions and implications of my findings.

\section{SECTION 2 - LITERATURE REVIEW}


In this review, I summarize the existing literature regarding the different areas covered in this study. First, I examine the international business literature on FDI spillovers. Second, I summarize the development economics literature on (i) FDI positive spillovers, (ii) FDI negative spillovers, and (iii) human development.

\section{FDI spillovers (international business)}

Examining the effects of FDI, researchers within management, international business, and development economics have highlighted FDI's powerful role on companies' and countries' fortunes (Gorg \& Strobl, 2001). FDI spillovers have been examined at the micro level (e.g., organizations) and macro level (e.g., countries) (Figini \& Gorg, 2011).

International business literature has mainly focused on FDI spillovers in domestic firms. FDI spillovers occur when MNEs produce benefits for domestic companies and in aggregate for the host country (Smarzynska Javorcik, 2004). An abundance of literature has studied FDI and productivity spillovers in relation to domestic firms (Caves, 1974; Eapen, 2012; Globerman, 1979; Head, Ries, \& Swenson, 1995; X. Liu, Siler, Wang, \& Wei, 2000). More specifically, MNEs are considered conduits of technology transfer (Buckley, Clegg, Wang, \& Cross, 2002; Z. Liu, 2008). This gives local firms and people the opportunity to learn by interacting with and observing their advanced technologies, which allows domestic firms to upgrade their technology, upskill their employees, and acquire new knowledge (Buckley et al., 2002). Another benefit of FDI spillovers is that knowledge can be generated by MNEs' research and development (R\&D) — that is, productivity in domestic firms is influenced by R\&D and export activities (Jefferson, Huamao, Xiaojing, \& Xiaoyun, 2006; Wei \& Liu, 2006). FDI has also been related to increased host-country competition; the effect of these benefits improves domestic efficiency, innovation, and 
productivity (Marcin, 2008). Also a number of studies suggest that FDI generates knowledge spillovers on the host countries. Given the importance of knowledge for developing technology and economic growth in the host country, the literature has investigated this widely. A recent review of knowledge spillover has developed an analytical framework that integrates both micro and macro level antecedents of spillovers, this review analyzed three different constructs magnitude, speed and scope. This paper also highlights the importance of internal and external networks as well as role of social and political context to activate the flow of knowledge (Perri \& Peruffo, 2016). Furthermore, FDI spillovers not only have been studied from a technology orientation, there has been found positive spillovers on managerial knowledge. These spillovers are diffused by tacit and explicit elements of management practices of MNEs (Fu, 2012).

Most recently, studies have highlighted the importance of treating FDI differently by considering its motivation, nature, tenure and origin (Aitken \& Harrison, 1999; De Mello, 1999; Zhang, Li, \& Li, 2014). For example, Driffield and Love (2007) have observed that FDI motivation predicted its various effects on host countries' domestic productivity. FDI motivation has been classified as technology exploiting and sourcing. Technology-exploiting FDI refers to MNEs that possess the "ownership" advantage, characterized by superior technology and capital stock quality (Driffield \& Love, 2007); technology-sourcing FDI refers to MNEs that bring in limited technology, and is motivated by the need to acquire more knowledge by targeting specific locations to seek that knowledge and newer technology. Driffield and Love's results suggest that hightechnology FDI has positive spillovers on the host country's productivity, while lowtechnology FDI leads to no productivity spillovers. Similarly, Ha \& Giroud (2015) 
addressed whether competence-creating or competence-exploiting activities by MNEs influence FDI spillovers on host country's firms, and found that competence-creating activities of MNEs generate positive technology spillovers. In addition, Zhang et al. (2010) have examined the diversity of FDI country origins on domestic firms' productivity, and found that this diversity can facilitate FDI spillovers by increasing the variety of technology and management practices that MNEs introduce into the host country. Summarizing previous findings, a large meta-analysis has established a positive relationship between FDI and productivity spillovers (Gorg \& Strobl, 2001). Recently, in another meta-analysis, Meyer and Sinani (2009) applied competitive dynamics theory and observed a curvilinear relationship between FDI spillovers and the host country's development level in terms of income, institutional framework, and human capital. Furthermore, a few studies have investigated the contingency factors such as the host countries' absorptive capacity as well as institutional factors to explain the difference on spillover effects (Du, Harrison, \& Jefferson, 2014; Sánchez-Sellero, Rosell-Martínez, \& García-Vázquez, 2014; Wang, Gu, Tse, \& Yim, 2013). Although such studies have become increasingly sophisticated, scholars have primarily studied FDI's effect on domestic firms and left its broader social consequences unexplored.

\section{FDI spillovers (development economics)}

Development economics scholars have examined MNEs and their effect on host and home countries (Blomström \& Kokko, 1998). Most of the literature has shown that FDI is positively related to economic growth (Borensztein et al., 1998), human capital, educational attainment (Kottaridi \& Stengos, 2010), and domestic productivity (Gorg \& Strobl, 2001; Kakwani, 1981). More recently, several studies have examined whether FDI enhances 
human development (Arcelus et al., 2005; Lehnert et al., 2013; De Schutter, Swinnen, \& Wouters, 2013; Reiter \& Steensma, 2010; Sharma \& Gani, 2004). Sharma and Gani (2004) have found a positive correlation between FDI and human development for middle- and low-income countries. Other studies have attempted to better understand this relationship by examining mediation and moderation effects. Lehnert et al. (2013) have concluded that the positive relationship between FDI and human development is mediated by the quality of national governance. Moreover, Reiter and Steensma (2010) have found this relationship to be moderated by FDI policy, and strongest when FDI policy restricts foreign investors from entering certain economic sectors. This study has also observed this relationship to be moderated by host-country corruption, and strongest when corruption is low. Similarly, Stiglitz (2006) has found a positive relationship between FDI and human development, with the strength of that relationship depending on the government's capability to regulate the right balance between itself and the markets.

Although it makes important contributions, this line of research has rarely connected with the substantial investigation that reveals evidence for negative FDI spillovers. Yet negative spillovers, particularly inequality, have been shown to adversely affect human development (Melamed \& Samman, 2013).

\section{Negative FDI spillovers}

FDI spillovers are not always positive. Studies have increasingly demonstrated that FDI has negative effects (Haddad \& Harrison, 1993); for example, Aitken and Harrison (1999) have found that foreign firms negatively affect domestic firms' productivity, and suggested that increasing competition in the domestic market causes a crowding-out effect for domestic firms (Aitken \& Harrison, 1999). Further, economic scholars have progressively raised 
concerns over growing inequality. While FDI may offer benefits to the economy in which they locate, it is unclear whether the majority of individuals will benefit to the same extent (Figini \& Gorg, 2011). For example, Herzer et al. (2014) have observed a positive relationship between FDI and income inequality. Similarly, FDI has been found to have a strong positive relationship with wage inequality (Aitken \& Harrison, 1999; Aitken, Harrison, \& Lipsey, 1996; Feenstra \& Hanson, 1997; Figini \& Gorg, 2011). These studies have examined FDI and its association with higher wages for skilled workers, concluding that FDI affects the income and employments prospects of less skilled workers (Figini \& Gorg, 2011; Herzer et al., 2014). This generates a rising demand for skilled workers, causing their wages to rise, and thus causing income and wage inequality to deteriorate (Aitken et al., 1996). In addition, various studies have argued that the extent to which FDI causes inequality depends on two factors: (i) FDI motivation and (ii) the host country's capabilities to absorb the effects. These studies have noted that FDI focused on hightechnology flows toward economies with high educational levels, further contributing to the development of human capital in these economies (Basu \& Guariglia, 2007; Blomström, Kokko, \& Mucchielli, 2003). Conversely, economies with low levels of initial human capital attract assets-exploiting FDI, which plays a smaller role in the future development of these economies (Blomström et al., 2003).

\section{Human development}

Human development has recently been advanced as an issue of academic discussion. Many researchers have emphasized that globalization and foreign capital have been studied by only exploring markets and countries, while its effects on people have been largely overlooked (Streeten, 1999). Consequently, several studies have recently examined the 
relationship between different predictors of human development. Sharma and Gani (2004) have studied FDI's influence on the expanded conception of socioeconomic progress, such as human development, and concluded that a positive correlation exists between FDI and human development— this suggests that FDI slightly improves human development (Sharma \& Gani, 2004). In addition, this study also found that FDI has a higher positive effect on middle-income countries (Sharma \& Gani, 2004).

Another determinant of human development is economic growth, which has been found to provide resources that facilitate sustained human development improvement (Ranis, Stewart, \& Ramirez, 2000). This study has found a strong positive relationship between economic growth and human development—in particular, Ranis et al. (2000) have highlighted the importance of government expenditure on health and education, which in turn boosts human development (Ranis et al., 2000). They have also identified another link between human development and economic growth: that increased human development also increases national income (Ranis et al., 2000). The study has concluded that a mutual reinforcing upward spiral exists between economic growth and human development, in which high levels of economic growth lead to high levels of human development (Ranis et al., 2000). Similarly, Anand and Sen (2000) have observed a positive relationship between economic sustainability and human development.

This thesis attempts to integrate present human development concerns with those of the future, and proposes the idea that future generations should receive the same attention those of today (Anand \& Sen, 2000). While it is often assumed that economic growth leads to development, this has not always led to improvements in human development (S. Sen \& Bhattacharya, 2001; Sharma \& Gani, 2004; Stiglitz, 2006); this is because human 
development depends on various other social and physical conditions, such as healthcare and access to education (S. Sen \& Bhattacharya, 2001).

In addition, the UNDP has closely studied how to enhance and advance human development. Employment has been identified as critical in this process, since it allows people to broaden their choices and opportunities (UNDP, 2015b). In addition this, other factors identified as creating better conditions for human development include participation in political and community life, environmental sustainability, human rights, and promoting equality and social justice (UNDP, 2015b). However, human development is also affected by four major challenges that have emerged in the last decade: climate change, poverty, the employment crisis, and inequality. These challenges affect human development by limiting people's opportunities and worsening their living standards (Hall, Hackmann, Van der Hoeven, \& Heintz, 2013). Thus, these studies have accentuated the importance of the various factors that can enhance and diminish human development. More pressingly, they suggest that human development requires a much more complex examination than simply identifying the positive and negative effects.

In this literature review, I have determined two important research gaps. First, there is a need to extend the present narrow view of how FDI spillovers affect host economies to encompass a social dimension. Unfortunately, international business scholars have thus far focused largely on the effects of FDI on domestic firms' productivity and learning, leaving human development unexplored. Second, previous studies have examined either the positive or negative effects of FDI on human development. However, as emphasized by Hall et al. (2013), human development faces major challenges in this decade, thus prompting a need to consider FDI's more integrated effects on human development. 


\section{SECTION 3 - THEORY AND HYPOTHESES}

I propose that modest levels of FDI enhance human development through economic growth and higher income, but that these positive benefits taper off as FDI increases. Alongside these benefits, the cost of FDI (greater income inequality) also increases which refers to the extent to which income is distributed in an uneven manner among a population (Inequality Org, 2017). I argue that these counteracting forces of positive and negative FDI effects on human development create an inverted U-shaped relationship (Haans, Pieters, \& He, 2016). In this study, the predictor is inward FDI stock which measures the total level of foreign direct investment at the end of year (UNCTAD, 2016). Particularly, it accumulates the value of foreign assets at a given point which captures long lasting effects. Furthermore, I adopt the United Nations' definition of human development which emphasizes that people and their capabilities should be the criteria for assessing the development of a country (UNDP, 2015b). This measurement comprises three components: (i) health, (ii) education, and (iii) income (UNDP, 2015b). In this section, I build my arguments for how FDI affects each of these components.

\section{Benefits of FDI for human development}

FDI can potentially promote technology and economic growth in the host country

(Borensztein et al., 1998). Incoming foreign investments boost economic growth and income in the host country through three mechanisms: (i) greater employment, (ii) greater revenue received by the government, and (iii) MNEs' technology diffusion. Such growth drivers collectively contribute to the host country's greater national economic 
competitiveness and human development (Ranis et al., 2000). It is reasonable to expect that the marginal positive effect of FDI will increase only at a decreasing rate.

First, FDI increases demand for employees, thus expanding labor force participation (Feenstra \& Hanson, 1997). This increased demand drives wage inflation and higher income for workers. Income, although potentially going toward a range of expenditures, also trickles down to factors associated with human development, such as education and health (Ranis et al., 2000). Indeed, higher income has been positively related to more years spent at school, and a higher average education threshold (Brückner \& Gradstein, 2013). Higher income potentially enables members of the host country's population to invest in their own and their family's education. This, in turn, enables individuals to undertake higher level skilled employment, or even to launch their own companies (Spender, 2013). This shift in income is also associated with health improvements (Bloom \& Canning, 2000), as individuals tend to spend a larger share of their income on healthcare and improving their living standards and, thereby, human development (Acemoglu, Finkelstein, \& Notowidigdo, 2013).

The second FDI benefit is increased government tax revenues, which then allow governments to increase investment and public spending (Basu, Chakraborty, \& Reagle, 2003) and allocate more resources to activities that contribute to human development. These could include the host country's social infrastructure to improve education, health, poverty rates, subsistence, or support for the unemployed, which in turn reduces poverty (Ranis et al., 2000).

Finally, the presence of MNEs encourages technology diffusion, which contributes to the host country's economic growth (Borensztein et al., 1998; Z. Liu, 2008; Walz, 1997). 
Technology diffusion can occur through knowledge transfer and exposure to new technology (Borensztein et al., 1998). MNE, with a broader network of subsidiaries spanning the globe, may have grown as a consequence of excelling in a variety of business areas such as strategy, innovation, technology, or management practices. These valuable practices can spill over to domestic firms and, as a result, enhance their efficiency and technology (Blomström \& Kokko, 1998; Z. Liu, 2008). Thus, technology diffusion can be an important conduit of economic development and growth (Borensztein et al., 1998) and translate to greater human development (Ranis et al., 2000).

\section{Costs of FDI for human development}

While FDI brings benefits to the host country, evidence also suggests that these benefits are not always evenly distributed across society. Some individuals benefit considerably more than others from such opportunities (Figini \& Gorg, 2011). Although foreign firms may require workers of all types, labor shortages for those with technical or managerial capabilities mean that these workers will be paid disproportionately more. For example, highly skilled and educated professionals who may be in short supply are more likely to reap the most benefit. Strong demand and higher wages in comparison with compatriots results in increasing income inequality. MNEs seek educated individuals and invest heavily in developing their capabilities by offering training and education to establish a highly skilled workforce. Some have argued that this phenomenon has accelerated with technology diffusion and rising international trade (Figini \& Gorg, 2011; Taylor \& Driffield, 2005). Further, the domestic labor market might experience the "skill-stealing effect," where MNEs demand the best workers and leave those less skilled (Girma, Greenaway, \& Wakelin, 2001). Such trends de-emphasize the role of less skilled labor, pushing income 
down for low-skilled workers. Moreover, MNEs generally pay higher wages for all type of employees than comparable domestic companies (Figini \& Gorg, 2011; Girma \& Görg, 2007; International Labour Organization, 2015). Thus, the increased demand for skilled workers and higher wages drives up income for high-skilled labor, widening the skilledunskilled income gap, and deepening inequality (Gopinath \& Chen, 2003; Herzer et al., 2014). The consequences of different rents being accrued by different sets of individuals is that FDI leads to increasing inequality (e.g., across wages, human capital, and income).

Inequality, especially income inequality, has a significant negative effect on the host country's development and growth (Basu \& Guariglia, 2007; Feenstra \& Hanson, 1997; Figini \& Gorg, 2011; Herzer et al., 2014). Income inequality refers to the concentration of wealth among a small proportion of the population, which reduces the spending power of most of the population. More importantly, it triggers reduced income and health (Ostry \& Berg, 2011). This restricts the accumulation of human capital and undermines education, hindering skills development for deprived individuals (Organization for Economic Cooperation and Development, 2014; Stewart \& Samman, 2014). In this study, given the robust link with economic prosperity, I focus on income inequality.

Higher rates of income inequality tend to substantially diminish per-capita income levels, slow economic improvement, deteriorate living standards, and increase poverty (Melamed \& Samman, 2013). At the individual level, income inequality creates a stratified society (i.e., a pyramid effect) with the majority of individuals at the bottom. These individuals might experience a stronger inequality effect, which has negative repercussions for income per capita, living standards, and educational development compared with those at the top. At the aggregate, national level, higher income inequality causes negative effects 
on the extent of growth spells (Cornia, 2004). The length of growth is critical to achieving sustainable development, which translates into equal opportunities and human development improvements (Ostry \& Berg, 2011). Therefore, countries with less equal income distribution tend to experience shorter and unsustainable growth periods (Ostry \& Berg, 2011). Further, health is significantly affected when income per capita decreases (Subramanian \& Kawachi, 2004) — individuals have fewer resources to invest in their own health, thus reducing their life expectancy. Income inequality results in high-income earners having better access to healthcare; by contrast, those who have not achieved a certain income threshold have difficulties accessing healthcare (Wilkinson \& Pickett, 2006).

Income inequality also negatively affects educational attainment (Mayer, 2000). The gap between low- and high-income earners results in a variation between their children's education levels, as it may reduce low-income individuals' capacity to invest in education (Ostry \& Berg, 2011). Affluent, higher income parents will have more resources to ensure their children's academic success, whereas children from low-income families start their educational life with more challenges and fewer resources (Haveman \& Smeeding, 2006). The uneducated labor force faces a lack of opportunities to generate higher income or obtain financial aid to assure their own and their children's education (Ostry \& Berg, 2011). Hence, students with fewer resources are less well prepared for academic life (Haveman \& Smeeding, 2006). Moreover, income inequality escalates the cost of high-quality education - for example, it elevates the cost of attending college far more for low-income students than for high-income students (Haveman \& Smeeding, 2006). This causes a lack of human capital in an environment where less skilled employees 
are unable to access education that facilitates earning greater income and access to modern technology (Basu \& Guariglia, 2007; Feenstra \& Hanson, 1997). Finally, income inequality has a contagion effect in that it is transferred to subsequent generations (Melamed \& Samman, 2013). It has particularly negative consequences for poorer children's educational outcomes and college graduation rates (Haveman \& Smeeding, 2006). For instance, in 2016 China is the third largest receiver of inward foreign investment. It received around US\$ 134 billion (UNCTAD, 2017). Yet, China's human development is 0.738 which is considered rank 90 around the world (UNDP, 2015a). Considering the largest amount of foreign investment, their human development is still very low and has not increased as much as it would have been expected. This phenomenon is increasingly raising in the world which supports our first argument. In sum, based on the above findings, the negative effects of FDI on human development increase while its positive effects increase, only at a decreasing rate. Hence, I expect:

Hypothesis 1: There is an inverted U-shaped relationship between inward FDI and human development in the host country.

\section{Moderating role of institutions: Business sophistication and transparency}

Institutions effectively define accepted business practices (i.e., the "rules of the game") in commerce and industry (Mair, Martí, \& Ventresca, 2012). Institutions are crucial to shaping and supporting the markets in which domestic and foreign firms interact (Campbell \&

Lindberg, 1990; De Soto, 2000; Greif, 2006; A. Sen, 1999). At the organizational level, institutions create and manage the existing rules that determine MNEs' actions and strategies in the host country (DiMaggio \& Powell, 1983). At an aggregate level, institutions play an important role in economic growth and the norms and accepted business 
practices that determine economic development (Webb, Tihanyi, Ireland, \& Sirmon, 2009). Therefore, it is important to understand and analyze how institutions channel FDI and, in turn, the expectations of MNEs and the business practices they implement (Banerjee \& Duflo, 2011). Yet there is considerable variation across different economies regarding the extent to which institutions might be present and strong, or absent and weak. Strong institutions connote an environment in which domestic players are already established and have secure regulations for businesses in the private sector and the transparent public sector. In this environment, new players become a part of an existing system and, as they are thus less likely to shape these markets, are more likely to comply with existing business rules and transparent regulations. Conversely, weak or absent institutions create an environment in which economies experience lack of knowledge and opportunities and relatively uncontrolled market systems (Crow, 2001; Mair et al., 2012; Rodrik, 2008), as a result of their limited clarity or transparency of expected business practices and regulations. Thus, new entrants have far greater latitude to be active participants that serve as agents of change (Kwok \& Tadesse, 2006).

In this study, I consider both private- and public-sector institutions. I use the term "business sophistication" as a proxy for institutions, practices, and business environment in the private sector. This includes a country's overall business networks and the quality of individual firms' operations and strategies (World Economic Forum, 2015). For publicsector institutions, I use the terms "transparency," "accountability," and "corruption index" as proxies for public-sector institutions and regulations. Transparency refers to the extent to which government employees are held accountable for administrative decisions and their use of funds and resources (World Bank, 2016). Economies that have little business 
sophistication and transparency are considered to have weak local institutions, while economies with high business sophistication and high transparency possess strong local institutions. This is important in terms of understanding the effects of FDI, as institutions play a significant role in determining how FDI is channeled and invested (Meyer \& Sinani, 2009) and are likely to influence the extent to which FDI enhances human development. In the following subsections, I explain my arguments when institutions are strong and weak for each of these two moderators: business sophistication and transparency.

\section{Business sophistication}

I theorize that the strength of the relationship between FDI and human development depends on the host nation's level of business sophistication. Business sophistication measures the extent to which a country possesses advanced supplier networks, technologically up-to-date production processes, and many elements of the value chain, from marketing and logistics to international sales structures. Three interrelated constructs regarding the extent to which a country possesses an advanced commercial economy have been identified by the World Economic Forum (2015) as the presence of (i) networks and suppliers (quality and quantity of suppliers and state of cluster development), (ii) the nature of the country's competitive advantage (competitive advantage and production process sophistication), and (iii) the extent to which existing domestic firms encompass a range of value chain activities (value chain breadth, control of international distribution, extent of marketing, and willingness to delegate authority). For less sophisticated economies, I predict that the relationship between FDI and human development takes the form of a more pronounced inverted U-shape. For more sophisticated economies, I predict that the inverted U-shaped curve will be weaker (attenuated) such that the increasing slope is less and the 
decreasing slope equally less negative. I now explain the arguments for each of these two scenarios based on the varying reasons MNEs have a different effect on benefits and costs.

In less sophisticated economies, international capital is invested in a relatively undeveloped business environment that lacks suppliers' products, processes, and marketing. To succeed, MNEs are more likely to need to build these elements, as they are required by every industry. International entrants must invest in a range of infrastructure to support their activities and success. With low levels of FDI, this is particularly important for boosting the local economy and fostering economic growth. These investments inject capital to advance business practice, which in turn generates more employment and increases workforce participation. Alongside this, foreign investments are more likely to provide higher revenue to governments and encourage the development of educational systems that support these industries; they also help enhance educational attainment and build human capital, which are key elements of economic growth (Barro \& Lee, 2001) and human development. Yet as MNEs' investment increases, the costs of this will most probably also rise. In this context, such capital shapes the economy and the role of foreign firms in the host country as a market maker, and MNEs then tend to have higher leverage and control over domestic firms, government, and local economy. Therefore, as a consequence of building the market, MNEs are feasibly able to negotiate reduced tax rates and favorable transactions that allow them to improve their profit margins. In addition, MNEs are more likely to offer high wages only to specific parts of the workforce (i.e., executives) who may be in short supply, and pay relatively low wages to the bulk of the workforce to drive down costs. MNEs thus create a gap between skilled and unskilled employees' income, minimizing incidental investment in education, training, and upgrading 
skills. As a consequence, rather than this capital being invested in the country and its social infrastructure, it goes toward MNEs reducing and constraining government income and wages. This diminishes wage growth and resources for health and education expenditure. Beyond this, given MNEs' powerful leverage as both a major source of capital and a probable market maker, they may even appropriate resources. In this context, MNEs pay minimal resources to their countries of investment, but substantially extract from these countries to increase their own profits; this translates to decreased human development. These different negative forces thus curtail the host country's resources for individuals and government, leading to rising income inequality and scant increases in government revenue, which significantly diminishes human development.

In comparison, sophisticated economies have a developed network market comprising technological- and knowledge-intensive processes and productions. These economies create the potential for superior technology and technical capabilities that reflect their sophisticated nature (Driffield \& Love, 2007). A key element of innovative national culture is the education level of the workforce, which is characterized by robust human capital supplier networks and developed business practices and strategies. These economies have a domestic incentive to enhance education and domestic market rules and procedures. To succeed, MNEs are more likely to adapt and follow domestic business practices since, in this context, the host country's business environment is well established and shapes the interaction between domestic and foreign firms' networks. At low levels of FDI, MNEs are less able to be active participants in the economy, and the host country will probably gain modest benefits, since it has achieved a certain level of economic development in its practices, strategies, and markets, and independence from foreign businesses. Thus, FDI 
boosts the host country's economic vibrancy, enhancing existing liquidity and investment. Yet, given these economies possess existing and developed markets the influence of FDI will be reduced. This translates to low and moderate increases in government income, economic growth and, in turn, human development.

Nevertheless, at high levels of FDI, MNEs are more likely to undertake a different role and shape the economy in which they acquire power and leverage in the host country. MNEs may influence these markets and take advantage of higher margins; this can generate lower government income and decrease workforce costs. This might trigger the negative costs associated with FDI, including less government income and higher leverage, which triggers income inequality in the host country. However, these negative costs are unlikely to be as high as those caused by new entrants in less sophisticated business markets. Thus, in high-sophisticated economies, FDI brings low benefits and costs, which translates to an attenuated relationship between FDI and human development:

\section{Hypothesis 2.1: Business sophistication moderates the inverted U-shaped} relationship between FDI and human development in such a way that the inverted U-shape will be steeper in locations with a low level of business sophistication and flatter in locations with a high level of business sophistication.

\section{Transparency}

I propose that the strength of the relationship between FDI and human development depends on the host nation's level of transparency. Transparency has been defined and measured by the World Bank (2016) as public-sector employees' accountability and transparency in terms of their decision-making processes and use of funds. This includes the presence of (i) executives' accountability to oversee institutions, (ii) public-sector 
employees' accountability and performance, and (iii) civil society's access to information about public affairs (World Bank, 2016). For economies with low transparency, I predict that the relationship between FDI and human development will take the form of a more pronounced inverted U-shape. For economies with high transparency, I predict that the inverted U-shaped curve will be weaker (attenuated), such that the increasing slope is less and the decreasing slope is equally less negative. Thus, low-transparency economies with low-to-moderate FDI levels will experience significant human development benefits, but these will decrease as the costs of FDI increase, thus diminishing human development. By contrast, high-transparency economies with low FDI levels will experience modest human development improvements. Equally, as FDI increases, as there are a few costs involved, there are limited negative or non-significant effects on human development. I now explain these two scenarios.

Economies with low transparency experience an absence of clarity and accountability regarding their executives and employees' decision-making, processes, and procedures in the public sector. These economies lack transparent government actions and existing, formal public-sector regulations. There is likely to be little clarity about government involvement in factors that affect human development and a resource-scarce environment in which social problems are abundant (Stephan, Uhlaner, \& Stride, 2015). In addition, these economies might experience higher corruption, which drains country funds, diminishing economic growth (Kwok \& Tadesse, 2006). The accumulation of these factors may trigger higher social needs (Dacin, Dacin, \& Matear, 2010), such as lack of education, health, and income. Consequently, these economies have higher need for improvements in public-sector policies, actions, and procedures. At low levels of FDI, MNEs are particularly 
helpful for developing the institutional environment in such a way that foreign business may positively influence the host country's policies and procedures, and be more likely to exercise regulatory and demonstration effects on the host country's public institutions (Kwok \& Tadesse, 2006). These effects put pressure on public institutions to restructure at a more global level, thus enabling them to gain legitimacy and enact clear and transparent policies and practices (Kwok \& Tadesse, 2006). These changes can potentially re-allocate funds to a more efficient and proper manner (Kwok \& Tadesse, 2006), thus increasing government revenue and, in turn, enhancing public expenditure on education, health, and higher income per capita. Therefore, FDI increases human development in the host country, offering opportunities for positive change and the restructure of public institutions by reallocating funds to government and increasing employees' wages.

Yet as FDI grows, the costs of FDI are also likely to rise. In this context, foreign capital might acquire more leverage over public practices and processes, which gives MNEs more control over public-sector funds. This increased leverage comes at a cost, affecting both individuals and the host country. Specifically, MNEs have greater opportunity to extract resources from the host country with little accountability. In this context, MNEs will probably try reducing business costs, which can lead to low pay rates for the majority of the workforce, and to offer higher pay to those influential in gaining access to key resources (i.e. permits) and public-sector executives and employees. In addition, public-sector employees are more likely to receive a higher salary. This phenomenon increases inequality between those who are more influential and those who are not. This rising inequality affects human development by depriving individuals with fewer resources access to education, health, and a decent income. Thus, these factors 
negatively shape human development by compromising individuals' access to vital resources.

By comparison, high-transparency economies are more likely to have clear and transparent rules, actions, and procedures within the host country's public sector (Stephan et al., 2015). These economies are characterized by active governments that are able to allocate resources more efficiently in an environment built on trust and ethical conduct (Kwok \& Tadesse, 2006). Moreover, these nations ensure legitimacy in their dealings with MNEs through joint ventures or business relationships such as value chains (Eden, Levitas, \& Martinez, 1997). Therefore, economies with high transparency can potentially allocate their resources efficiently and effectively, which allows them to acquire better capabilities in terms of social and economic benefits and thus establish a more robust public sector, and to meet social needs such as education, health, and income. At low levels of FDI, new foreign entrants are unlikely to contribute as much to the development of the public sector; these economies might achieve standardized clear and transparent policies, procedures, public-sector employee roles. Thus, when FDI has minimal effects on a host economy, the human development benefits are also smaller. As opposed to economies with low transparency, as FDI increases in high-transparency economies, MNEs are less able to gain leverage and control over public policies, processes, and practice. Specifically, governments in these economies are liable to be accountable for their actions and possess firm, transparent policies; foreign companies will thus experience a well-regulated public sector. MNEs might find it difficult to gain advantage and leverage over resources and funds. Therefore, the costs associated with the effects of FDI on the host country's public 
sector and, more importantly, FDI's negative consequences on human development are non-significant. These arguments lead to the following hypothesis:

Hypothesis 2.2: Transparency moderates the inverted U-shaped relationship between FDI and human development in such a way that the inverted U-shape will be steeper in locations with a low level of transparency and flatter in locations with a high level of transparency.

\section{SECTION 4 - DATA AND METHODOLOGY}

I now attempt to explain the cross-country variation on human development based on the extent of foreign investment in different economies. Because of the methodological constraint of the dependent variable, which can only be measured at the country level, the best data fit for this study is at the aggregated level. Therefore, I constructed a database comprising a set of variables from various sources to take advantage of these variables' diversity and controls. Measures of human development (the dependent variable) and its components (education index, health index, and income per capita) come from the UNDP (2015a), measures of foreign investment (the independent variable) come from the UNCTAD (2016), and the moderators (business sophistication and transparency index) come from the World Economic Forum (2016) and the World Development Indicators (World Bank, 2016). Finally, other controls were collected from the International Monetary Fund (2016) and the World Development Indicators (World Bank, 2016). My sample is an unbalanced panel data that includes these sets of variables up to 139 countries over 14 years (2000-2014), which allowed me to analyze the data as panel. In addition, I lagged all 
country-level variables by at least one year to reduce potential endogeneity between the hypothesized antecedents and the outcome variable.

\section{Dependent variable}

The dependent variable was measured by the Human Development Index (HDI), which measures the development of a country based on their population capabilities. This measure combines three important aspects: a long and healthy life, knowledge, and a decent standard of living (UNDP, 2015b). A long and healthy life was measured by life expectancy at birth. The ability to acquire knowledge was measured by mean years of schooling and expected years of schooling. Finally, the ability to achieve a decent standard of living was measured by Gross National Income (GNI) per capita. HDI was an unweighted average of these three aspects, with an upper limit of 1.0 (UNDP, 2015b). This measurement was considered the best fit for this study, as it includes both economic and social aspects. In addition, the three elements were considered separately in the analysis as robustness tests. The data were collected from the UNDP (2015a) database.

\section{Independent variable}

FDI was measured by inward FDI stock which was presented at book value (historical cost). This measure contains the inward investments on the original price at the time it was made-it accumulates FDI inflows over a period, which effectively captures the long-term effects. FDI inflows captures incoming flows from MNEs, such as equity capital, reinvestment of earnings, and other short and long-term capital (Basu \& Guariglia, 2007). These inflows were presented on net bases (new investment inflows less disinvestment), or capital transactions' credits less debits between direct investors and their foreign affiliates (Kottaridi \& Stengos, 2010). Net decreases in assets or net increases in liabilities were 
recorded as credits (with a positive sign), while net increases in assets or net decreases in liabilities were recorded as debits (with a negative sign). Further, as part of the robustness tests, two different constructs were used as a predictor of human development: FDI inflows and inward FDI stock as a percentage of GDP (inward FDI stock/GDP) to verify that the results supported the main effects. These data were collected from the UNCTAD (2016).

\section{Moderators}

Business sophistication represents two linked elements: the quality of a country's overall business networks and the quality of individual firms' operations and strategies (World Economic Forum, 2015). First, the quality of business networks and supporting industries was measured by the quantity and quality of local suppliers and the extent of their interaction. Second, individual firms' operations and strategies were measured by the spillover effect of branding, marketing, distribution, advanced production processes, and the production of unique and sophisticated products into the economy, leading to sophisticated and modern business processes across the country's business sectors (World Economic Forum, 2015). The index used was a 7-point scale, with 1 the lowest and 7 the highest. The data were collected from the World Economic Forum database (World Economic Forum, 2016). Appendix 1 summarizes the measurements of this index.

Transparency index was measured by three main public-sector dimensions. First, executives' accountability in terms of overseeing institutions, and public-sector employees' accountability and performance; second, civil society's access to information about public affairs; and third, the state capture by narrow vested interests. The index used was a 6-point scale, with 1 the lowest and 6 the highest. The transparency index is part of the Country 
Policy and Institutional Assessment database, and the data were collected from the World Bank (2016).

\section{Controls}

Foreign aid is considered one of the most important sources of foreign funding for human development and economic growth (Gomanee, Girma, \& Morrissey, 2005; Kosack \& Tobin, 2006). The UNDP (2015b) has pointed out that foreign donors significantly contribute to achieving greater human development. The data represent the net bilateral aid flows from Development Assistance Committee (DAC) donors, which are the net disbursements of official development assistance or official aid from DAC members. Net disbursements are gross payments of grants and loans minus repayments of principal on earlier loans. The data were collected from the World Development Indicators (World Bank, 2016).

Trade openness was defined and measured as total imports plus total exports (Figini \& Gorg, 2011). Countries have increasingly opened their trade barriers and allowed more inward FDI as part of the growing interconnectivity and advancement of globalization, such as industrialization and technology (World Commission on the Social Dimension of Globalization, 2004). Trade openness affects human development via two different paths. First, countries begin exporting more, boosting economic growth and income. Second, trading allows countries to gain knowledge, expertise, and technology (Cooray, Mallick, \&

Dutta, 2014). The data were collected from the World Development Indicators (World Bank, 2016) and presented as percentages of GDP.

Government savings have also been considered a determinant of human development; countries with higher savings tend to have better human and economic 
performance (Caceres \& Caceres, 2015). In particular, the importance of savings has been demonstrated in a comparison made by Thimann and Dayal-Gulati (1997) between South East Asia and Latin America, revealing that regions with greater savings improved their development. In this study, this was measured by the gross national savings as a percentage of GDP, and data were collected from the International Monetary Database (International Monetary Fund, 2016).

Gross national expenditure is the amount of money the government and the population expend in the host country. Governments' spending on social infrastructure (e.g., hospitals, schools) facilitates better systems for, and access to, basic human needs, thus improving human development. Second, increased expenditure from the population means that people have more opportunities to earn and spend on education to develop their capabilities (Kottaridi \& Stengos, 2010). The data represent the sum of household final consumption expenditure, general government final consumption expenditure, and gross capital formation. This construct was measured in constant US dollars using the exchange rate of 2005 and the data were extracted from the World Development Indicators (World Bank, 2016).

GDP has been proven to lead to better human development (Ranis et al., 2000). The data represent GDP at purchasers' prices, which is the sum of gross value added by all resident producers in the economy plus any product taxes and minus any subsidies not included in the products' value. It was calculated without making deductions for depreciation of fabricated assets or for depletion and degradation of natural resources. The data were extracted from the World Development Indicators and expressed in constant US 
dollars using the exchange rate of 2005. Dollar figures for GDP were converted from domestic currencies using 2005 official exchange rates (World Bank, 2016).

\section{Methodology}

To examine my hypotheses, I used ordinary least squares (OLS) estimation with fixed effects. More specifically, I tested for fixed versus random effect using the Hausman test. Based on this test, I employed the fixed effects model. The advantage of estimating fixed effects is that it accounts for time-invariant factors that exhibit systematic variations across countries; controlling for these factors thus accounted for any unobserved heterogeneity across countries. Following this line of enquiry, countries may not only contrast in terms of their systematic societal characteristics, but feature varying slopes to their growth paths because of prolonged differences such as technological progress (Binder \& Georgiadis, 2010). Generally, in panel data analysis, the fixed effects model assumes that each country

differs in its intercept term (Ranjan \& Agrawal, 2011). Finally, the use of a lagged structure across the model allowed for a stricter test of the causal relationship.

In addition, I followed the three-step procedures used by Haans et al. (2016) to test the inverted U-shaped relationship. First, the FDI coefficient $\left(\beta_{\mathrm{FDI}}\right)$ had to be positively significant and the FDI-squared coefficient $\left(\beta_{\text {FDI-squared }}\right)$ had to be negatively significant. Second, the slope had to be sufficiently steep at both ends of the data range. I took two points at the low and high end of the X-range, the lowest point of FDI $\left(\mathrm{FDI}_{\mathrm{L}}\right)$, and the highest point of FDI $\left(\mathrm{FDI}_{\mathrm{H}}\right)$. I tested for an inverted U-shaped relationship, showing that the slope at the lowest point of FDI using $\beta_{\mathrm{FDI}}+2 \beta_{\mathrm{FDI}-\text { squared }} * \mathrm{FDI}_{\mathrm{L}}$ was positive and significant, and the slope at the highest point of FDI using $\beta_{\mathrm{FDI}}+2 \beta_{\mathrm{FDI}-\mathrm{squared}} * \mathrm{FDI}_{\mathrm{H}}$ was negative and significant. Finally, I tested the turning point of the inverted U-shaped 


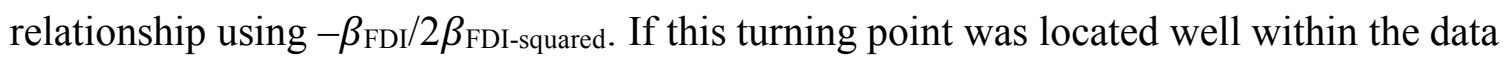
range, it established the existence of an inverted U-shaped curve.

\section{SECTION 5 - ANALYSIS AND RESULTS}

In this thesis, the analysis includes two sets of results. The first analysis includes government expenditure as a control variable (Tables analysis I). Nonetheless the correlations and further tests such as the variance inflation factor results on government expenditure highlighted a problem with collinearity. As a consequence, a second analysis was run in which government expenditure has not been included as a control variable (Tables analysis II). Fortunately, these two different analysis have been similar and both sets of results supported the hypothesis. The results discussed in the following section belong to the second analysis.

In tables analysis II, Table 1 presents the correlation matrix and descriptive statistics for the model variables. Table 2 presents the results for the OLS with fixed effects estimation, testing hypotheses $1,2.1$, and 2.2 . Table 3 presents the results for tests of the inverted U-shape for main effects and moderation effects. Tables 4 and 5 present the robustness tests of the main effects and the human development components, respectively. Tables 6 and 7 present the robustness tests of the inverted U-shape. Finally, table 8 presents the multicollinearity test results.

\section{Descriptive statistics}

Table 1 shows that, on average, FDI has a positive correlation with human development. This provides general support for the idea that FDI contributes to human development. In addition, business sophistication and transparency also positively correlate with human 
development. However, the correlations between major variables are high, suggesting that multicollinearity might be a problem. In order to mitigate this problem, I examined the variance inflation factors. Table 8 shows that the mean variance inflation factor is 3.60 which indicates low collinearity.

\section{Main effects and moderation effects}

Table 2 presents the main effects of FDI on human development and tests the moderation effects of institutions. Model 1 contains the control variables, and the subsequent model contains the main effects of FDI and human development and the moderation effects. I found strong support for Hypothesis 1 (Model 2), which describes an inverted U-shaped relationship between FDI inflows and human development, as the main effect of FDI is positive and significant $(\beta=0.006, \mathrm{p}<0.001)$ and the extent of FDI inflows squared is negative and significant $(\beta=-0.000, \mathrm{p}<0.001)$.

I also conducted the three-step procedure suggested by Haans et al. (2016) to test the inverted U-shaped relationship between FDI and human development shown in Table 3 (Model 1). First, the main effects of inward FDI stock and inward FDI stock squared coefficients are statistically significant and of the expected sign. Second, the slope analysis is positive and significant at low levels of FDI $(\beta=0.006, \mathrm{p}<0.001)$ and negative and significant at high levels of FDI $(\beta=-0.004, \mathrm{p}<0.001)$. Third, the turning point of the inverted U-shaped curve is well located within the data range. Thus, these findings provide evidence in support of the inverted U-shaped relationship between FDI and human development.

Hypotheses 2.1 and 2.2 are supported (Table 2), and the results endorse the moderating role of institutions, as the interaction term between inward FDI stock squared 
and business sophistication is statistically significant and with the expected sign $(\beta=0.000$, $\mathrm{p}<0.01)$. In addition, the analysis also supports the significance of the interaction term between inward FDI stock squared and transparency $(\beta=0.003, p<0.001)$. These results offer support for the idea that institutions moderate the relationship between FDI and human development.

To more accurately explain and display how business sophistication and transparency affect the nonlinear relationship between FDI and human development, I plotted the moderating relationships (Aiken, West, \& Reno, 1991), and considered margins to draw these graphs one standard deviation below and above the mean to represent the low and high values of business sophistication and transparency. Figure 2 shows the moderating effects of business sophistication (Hypothesis 2.1). The interaction graph indicates that countries with low business sophistication exhibit a steeper inverted U-shaped curve between FDI and human development. However, the graph shows that for the negative slope at high levels of FDI, the confidence intervals are wide. This might indicate that the sample size for this side of the curve is small. Conversely, high business sophistication appears to facilitate a slightly positive relationship between FDI and human development, indicating that the moderation has a flattening effect. These results confirm Hypothesis 2.1, which suggests that the inverted U-shaped curve is flatter in countries with high business sophistication than in those with low business sophistication.

Figure 3 illustrates how transparency moderates the nonlinear relationship between FDI and human development (Hypothesis 2.2). According to expectations, countries with low transparency experience a rather steep curve between FDI and human development. However, the figure shows that the confidence intervals are wide for the negative slope of 
the graph, indicating that the sample size is small. On the contrary, in line with Hypothesis 2.2, I found that countries with high transparency experience a flatter inverted U-shaped curve between FDI and human development. Thus, these results show that the hypothesized direction of the curve accords with expectations.

\section{Robustness analysis}

To verify my findings with greater confidence, I performed several robustness tests.

First, I tested the model using alternative measures of FDI, FDI inflows, and FDI stock as a percentage of GDP (FDI stock/GDP). I found the results to be consistent with those of the main effects, supporting an inverted U-shaped curve. The results are illustrated in Table 4 and reveal that the main effects between FDI inflows and FDI stock/GDP are positive and statistically significant $(\beta=0.027, \mathrm{p}<0.001 ; \beta=0.001, \mathrm{p}<0.001)$. In addition, the effects of FDI inflows and FDI stock/GDP squared are negative and statistically significant $(\beta=-0.003, \mathrm{p}<0.001 ; \beta=-0.000, \mathrm{p}<0.001)$.

Second, I tested that inward FDI stock has an inverted U-shaped relationship with each of the human development components. The results are illustrated in Table 5 and support FDI's significantly positive effects on education (Model 1), health (Model 2), and income per capita (Model 3), respectively $(\beta=0.009, \mathrm{p}<0.001 ; \beta=0.004, \mathrm{p}<0.001 ; \beta=$ 362.392, $\mathrm{p}<0.001)$. The effects of FDI-squared are negative and significant, respectively $(\beta=-0.000, \mathrm{p}<0.001 ; \beta=-0.000, \mathrm{p}<0.001 ; \beta=-3.413, \mathrm{p}<0.001)$. Additionally, I tested the relationship between FDI inflows and inward FDI stock/GDP and the components of human development. The results are consistent with the effects of FDI inflows, supporting the inverted U-shaped relationship in each component. 
Third, I conducted the moderations analysis on the relationship between FDI inflows and inward FDI stock/GDP. The results are illustrated in Table 6. Models 1 and 2 show that the moderation effect of institutions on the relationship between FDI inflows and human development support the analysis from the main effects. The interaction term between FDI inflows-squared and business sophistication is statistically significant and with the expected $\operatorname{sign}(\beta=0.004, \mathrm{p}<0.001)$. In addition, the analysis supports the significance of the interaction term between FDI inflows-squared and transparency $(\beta=$ $0.120, \mathrm{p}<0.01)$. However, the results do not show support for the moderation effect of business sophistication on the relationship between inward FDI stock/GDP and human development. The interaction term between inward FDI stock/GDP-squared and transparency is statistically significant and with the expected sign $(\beta=0.000, \mathrm{p}<0.01)$.

Finally, I conducted the three-step procedures suggested by Haans et al. (2016) to test the inverted U-shaped relationship between FDI inflows and inward FDI stock/GDP and human development. Table 7 illustrates the results and supports each of the three steps to confirm the inverted U-shaped relationship. Thus, these findings provide evidence in support of the inverted U-shaped relationship between FDI inflows and inward FDI/GDP and human development. In addition, I performed the three-step procedure to confirm the existence of an inverted U-shaped relationship between FDI inflows and inward FDI stock/GDP and each of the human development components. The results support the existence of a U-inverted shaped relationship. 


\section{SECTION 6 - DISCUSSION}

This research was motivated by the desire of better understand how FDI affects human wellbeing and broadens people's choices and opportunities. This thesis contributes to the literature by examining the fundamental effects of FDI on human development. As noted earlier, prior research has primarily prioritized FDI's effect on economic growth, domestic productivity, and knowledge spillover. While these studies have been crucial to understand FDI effects, this research is the first one that considers the counteracting positive and negative effects of FDI on a social outcome (human development). Finally, this thesis is also innovative in terms of identifying contingencies of the FDI effects.

The main contributions of this thesis attempt to meet the lacking literature on (i) the effect of inward FDI on human development and (ii) the integrated outcome of both positive and negative effects of FDI. First, this study demonstrates that FDI has an inverted U-shaped relationship with human development. At modest levels, FDI increases human development; yet as FDI increases, it leads to a negative association with human development. While FDI offers benefits that enhance human development, such as host country's economic growth and higher income which in turn are likely to encourage governments and individuals to spend more on education and health. It has also a negative effect on human development by distributing these benefits unevenly, this research demonstrates that a key cost of FDI for human development is income inequality (Basu \& Guariglia, 2007; Chintrakarn, Herzer, \& Nunnenkamp, 2012; Choi, 2006; Herzer, Hühne, \& Nunnenkamp, 2014; Pan-Long, 1995). This could lead to inequalities in income, education, and health. Thus, FDI might improve the host country's economic growth and income, but that improvement might not be reflected on individuals' lives and development 
due to the increased inequality. Second, given FDI's counteracting positive and negative effects on human development, the results suggested that the net effect of these counteracting arguments is a curvilinear, inverted U-shaped relationship. These results are consistent with my predictions that FDI enhances economic growth and high income in the host country (Borensztein, De Gregorio, \& Lee, 1998), and exerts a positive effect on human development. However, alongside these benefits, FDI also increases income inequality (Herzer et al., 2014); ultimately, these negative effects will outweigh FDI's initial positive benefits which result in an inverted U-shaped relationship.

Third, I drew upon the FDI's contingent effects argument (Meyer \& Sinani, 2009) which highlights the importance to understand when FDI effects affect differently. In doing so, I use the host country's institutional maturity in its private and public sectors to examine how the role of institutions affects the relationship between FDI and human development. My findings showed that the inverted U-shaped relationship between FDI and human development is moderated by the development of the host country's institutions. Particularly, the results showed that less sophisticated economies experience a steeper inverted U-shaped curve between FDI and human development. These economies are more likely to experience higher benefits that enhance human development; however, they are also likely to experience higher costs, which decrease human development. Conversely, sophisticated economies have a flatter inverted U-shaped curve, and are more likely to have developed markets and thus experience fewer benefits; however, at higher levels of FDI, the cost associated with foreign investment might rise. In addition, low-transparency economies experience a steeper U-shaped curve than those that possess high transparency. These economies will probably have a poorly regulated public environment where MNEs 
are more able to introduce higher benefits; however; this means they can also take advantage of these economies, thus incurring more costs. Conversely, high-transparency economies experience fewer benefits and costs, since they are more likely to possess a regulated public sector in which there is minimal space for MNEs to take control and gain leverage. In sum, these moderations are particularly important for supporting this thesis's main hypothesis and understanding FDI's contingent effects on human development. This demonstrates the importance of the host country's institutional development which can affect the extent of the benefits and costs of FDI. This thesis corroborates the concept that strategically, FDI is most important for countries that most strongly require it, but it is also more likely to harm these countries.

\section{Practical Implications}

My findings have important implications for governments, MNEs, people and policy makers. The results suggest that while host countries will most probably benefit from FDI, they will also most probably incur in its costs. This highlights the importance of integrating FDI benefits and costs; a key consideration is that host economies must exercise caution in welcoming FDI. MNEs are more likely to boost host countries' economic growth, income, and business environments, yet will also weaken host economies via associated costs such as inequality. This study suggests that FDI is not fostering human development as much as economic growth — therefore, host economies must be more careful in their approach to FDI, and analyze the possible benefits and costs associated with people's lives and how host economies can achieve certain levels of human development.

This study also emphasizes the importance of context for host country economies. Both the private- and public-sector moderators attained similar results in this study, despite 
the differences between the two sectors. In economies with weak institutions, MNEs are likely to benefit host country institutions through demonstration effects, knowledge transfer, and requiring firmly established practices and processes. These foreign firms play an integral role in shaping the economy to create a better business market, and acting as agents of change that can facilitate clear and transparent practices and policies. However, this excessive power and leverage can lead to associated costs for the economy that can weaken both it and the host country's society.

The results also provide suggestions for policy makers on how to manage FDI inflows in order to maximize its benefits to human development. The unblind call to bring FDI at a fast pace to the host country is not always the best approach, host countries need to consider the costs involve. Therefore, limits on FDI inflows should be established in order to avoid an excess of control and leverage that might result on hurting the host country's economy. In addition, my results demonstrate that institution's maturity has an important role on FDI effects, sophisticated economies benefit from FDI at a more regulated rhythm. While less sophisticated economies experience greater benefits but also greater costs. Thus, while FDI should be considered a factor in economic growth, development and a source of knowledge, economies must also establish their own set of rules and processes to reduce foreign firms' leverage and control of resources.

\section{Limitations and future research}

This study has a few limitations that offer opportunities for future research in this area. Many of the limitations of this study arise from the data used to analyze the model proposed. First, the human development measurement was only available at the country level, therefore the thesis model was adapted to be tested at the country level. Second, the 
data available at the country level were unbalanced panel data—some countries possessed complete information, while others did not. Third, I examined the model of this thesis using variables with different nature (i.e. indexes, flows, stock), this limitation might require additional analysis to expand whether mixing these different types of variables might be appropriate. Fourth, the confidence intervals on the negative slopes are wide, indicating that the data sample is small. Subsequently, the high correlation and variance inflation factor of government expenditures does arise a concern of multicollinearity. Finally, while endogeneity and reverse causality have been considered in this study through the interaction effect in the moderation process. This should be tested more rigorously.

In addition, other limitations such as the nature and intensity of FDI might have an effect on human development. For instance, different types of FDI generate demand for different pools of skilled and unskilled labor and these differences might influence human development differently. Furthermore, the period of time that foreign investment takes to establish in the host country might affect human development and income inequality. A time-series type of analysis might be desirable, showing the evolution of FDI stock over 14-year period in a particular country and how that relates to its human development and also institutions maturity over time. This analysis might highlight the process of FDI in a host country as well as the existing deficiencies or capabilities.

Future studies may examine the effects of FDI on more precise social outcomes such as education and health, there is a lack of understanding on how FDI has an impact on individuals and their lives. Another important opportunity may be to consider the differences on the nature of FDI, entry strategies, technology oriented, resources oriented and specific time dimensions of these flows. These differences might help understanding 
how the effects of FDI on the host country are different and which one is more beneficial.

Finally, future research may consider different contingency effects of the host countries that might affect the FDI effects. This will enable host countries to understand and more accurately plan for their FDI strategy. 


\section{REFERENCES}

Acemoglu, D., Finkelstein, A., \& Notowidigdo, M. J. (2013). Income and health spending: Evidence from oil price shocks. Review of Economics and Statistics, 95(4), 1079-1095.

Aiken, L. S., West, S. G., \& Reno, R. R. (1991). Multiple regression: Testing and interpreting interactions. Thousand Oaks, CA: Sage.

Aitken, B., Harrison, A., \& Lipsey, R. E. (1996). Wages and foreign ownership: A comparative study of Mexico, Venezuela, and the United States. Journal of International Economics, 40(3-4), 345-371.

Aitken, B. J., \& Harrison, A. E. (1999). Do domestic firms benefit from direct foreign investment? Evidence from Venezuela. American Economic Review, 89(3), 605-618.

Anand, S., \& Sen, A. (2000). Human development and economic sustainability. World Development, 28(12), 2029-2049.

Arcelus, F. J., Sharma, B., \& Srinivasan, G. (2005). Foreign capital flows and the efficiency of the HDI dimensions. Global Economy Journal, 5(2), 1-12.

Banerjee, A. V., \& Duflo, E. (2011). Poor economics: A radical rethinking of the way to fight global poverty. New York, NY: Public Affairs.

Barro, R. J., \& Lee, J. W. (2001). International data on educational attainment: Updates and implications. Oxford Economic Papers, 53(3), 541-563.

Basu, P., Chakraborty, C., \& Reagle, D. (2003). Liberalization, FDI, and growth in developing countries: A panel cointegration approach. Economic Inquiry, 41(3), 510-516.

Basu, P., \& Guariglia, A. (2007). Foreign direct investment, inequality, and growth. Journal of Macroeconomics, 29(4), 824-839. 
Binder, M., \& Georgiadis, G. (2010). Determinants of human development: Insights from statedependent panel models (UNDP-HDTO Occasional Papers No. 2010/24).

Blomström, M., \& Wolff, E. N. (1994). Multinational corporations and productivity convergence in Mexico.

Blomström, M. (1986). Foreign investment and productive efficiency: The case of Mexico. The Journal of Industrial Economics, 35(1), 97-110.

Blomström, M., \& Kokko, A. (1998). Multinational corporations and spillovers. Journal of Economic Surveys, 12(3), 247-277.

Blomström, M., Kokko, A., \& Mucchielli, J.-L. (2003). The economics of foreign direct investment incentives. In R. Lipsey \& H. Herrmann (Eds), Foreign direct investment in the real and financial sector of industrial countries (pp. 37-60). New York, NY: Springer.

Blomström, M., \& Persson, H. (1983). Foreign investment and spillover efficiency in an underdeveloped economy: Evidence from the Mexican manufacturing industry. World Development, 11(6), 493-501.

Bloom, D. E., \& Canning, D. (2000). The health and wealth of nations. Science, 287(5456), 12071209.

Borensztein, E., De Gregorio, J., \& Lee, J.-W. (1998). How does foreign direct investment affect economic growth? Journal of International Economics, 45(1), 115-135.

Brückner, M., \& Gradstein, M. (2013). Income and schooling. Retrieve from http://voxeu.org/sites/default/files/file/DP9365.pdf

Buckley, P. J., Clegg, J., Wang, C., \& Cross, A. R. (2002). FDI, regional differences and economic growth: Panel data evidence from China. Transnational Corporations, 11(1), 1-28. 
Caceres, L. R., \& Caceres, S. A. (2015). Financing investment in sub-Saharan Africa: Savings, human development, or institutions? The Journal of Developing Areas, 49(4), 1-23.

Campbell, J. L., \& Lindberg, L. N. (1990). Property rights and the organization of economic activity by the state. American Sociological Review, 55(5), 634-647.

Caves, R. E. (1974). Multinational firms, competition, and productivity in host-country markets. Economica, 41(162), 176-193.

Chintrakarn, P., Herzer, D., \& Nunnenkamp, P. (2012). FDI and income inequality: Evidence from a panel of US states. Economic Inquiry, 50(3), 788-801.

Choi, C. (2006). Does foreign direct investment affect domestic income inequality? Applied Economics Letters, 13(12), 811-814.

Cooray, A., Mallick, S., \& Dutta, N. (2014). Gender-specific human capital, openness and growth: Exploring the linkages for South Asia. Review of Development Economics, 18(1), 107-122.

Cornia, G. A. (2004). Inequality, growth, and poverty in an era of liberalization and globalization. Oxford, England: Oxford University Press on Demand.

Crow, B. (2001). Markets, class and social change: Trading networks and poverty in rural South Asia. New York, NY: Springer.

Dacin, P. A., Dacin, M. T., \& Matear, M. (2010). Social entrepreneurship: Why we don't need a new theory and how we move forward from here. The Academy of Management Perspectives, 24(3), 37-57.

De Mello, L. R. (1999). Foreign direct investment-led growth: Evidence from time series and panel data. Oxford Economic Papers, 51(1), 133-151. 
De Schutter, O., Swinnen, J. F., \& Wouters, J. (Eds.). (2013). Foreign direct investment and human development: the law and economics of international investment agreements. Routledge.

De Soto, H. (2000). The mystery of capital: Why capitalism triumphs in the West and fails everywhere else. New York, NY: Basic Civitas Books.

DiMaggio, P., \& Powell, W. W. (1983). The iron cage revisited: Collective rationality and institutional isomorphism in organizational fields. American Sociological Review, 48(2), $147-160$.

Driffield, N., \& Love, J. H. (2007). Linking FDI motivation and host economy productivity effects: Conceptual and empirical analysis. Journal of International Business Studies, 38(3), 460473.

Du, L., Harrison, A., \& Jefferson, G. (2014). FDI spillovers and industrial policy: The role of tariffs and tax holidays. World Development, 64, 366-383.

Eapen, A. (2012). Social structure and technology spillovers from foreign to domestic firms. Journal of International Business Studies, 43(3), 244-263.

Eden, L., Levitas, E., \& Martinez, R. J. (1997). The production, transfer and spillover of technology: Comparing large and small multinationals as technology producers. Small Business Economics, 9(1), 53-66.

Feenstra, R. C., \& Hanson, G. H. (1997). Foreign direct investment and relative wages: Evidence from Mexico’s maquiladoras. Journal of International Economics, 42(3), 371-393.

Figini, P., \& Gorg, H. (2011). Does foreign direct investment affect wage inequality? An empirical investigation. The World Economy, 34(9), 1455-1475.

Fu, X. (2012). Foreign direct investment and managerial knowledge spillovers through the diffusion 
of management practices. Journal of Management Studies, 49(5), 970-999.

Girma, S., Greenaway, D., \& Wakelin, K. (2001). Who benefits from foreign direct investment in the UK? Scottish Journal of Political Economy, 48(2), 119-133.

Girma, S., \& Görg, H. (2007). Evaluating the foreign ownership wage premium using a differencein-differences matching approach. Journal of International Economics, 72(1), 97-112.

Globerman, S. (1979). Foreign direct investment and "spillover" efficiency benefits in Canadian manufacturing industries. Canadian Journal of Economics, 12(1), 42-56.

Gomanee, K., Girma, S., \& Morrissey, O. (2005). Aid, public spending and human welfare: Evidence from quantile regressions. Journal of International Development, 17(3), 299-309.

Gopinath, M., \& Chen, W. (2003). Foreign direct investment and wages: A cross-country analysis. Journal of International Trade \& Economic Development, 12(3), 285-309.

Gorg, H., \& Strobl, E. (2001). Multinational companies and productivity spillovers: A metaanalysis. The Economic Journal, 111(475), 723-739.

Greif, A. (2006). Family structure, institutions, and growth: The origins and implications of Western corporations. The American Economic Review, 96(2), 308-312.

Ha, Y. J., \& Giroud, A. (2015). Competence-creating subsidiaries and FDI technology spillovers. International Business Review, 24(4), 605-614.

Haans, R. F., Pieters, C., \& He, Z. L. (2016). Thinking about U: Theorizing and testing U-and inverted U-shaped relationships in strategy research. Strategic Management Journal, 37(7), $1177-1195$.

Haddad, M., \& Harrison, A. (1993). Are there positive spillovers from direct foreign investment?: 
Evidence from panel data for Morocco. Journal of Development Economics, 42(1), 51-74.

Hall, J., Hackmann, C., Van der Hoeven, R., \& Heintz, J. (2013). Issues for a global human development agenda. Retrieved from http://hdr.undp.org/sites/default/files/issues_for_a_global_human_development_agendahdro-feb_2013.pdf

Haveman, R., \& Smeeding, T. (2006). The role of higher education in social mobility. The Future of Children, 16(2), 125-150.

Head, K., Ries, J., \& Swenson, D. (1995). Agglomeration benefits and location choice: Evidence from Japanese manufacturing investments in the United States. Journal of International Economics, 38(3), 223-247.

Herzer, D., Hühne, P., \& Nunnenkamp, P. (2014). FDI and income inequality-evidence from Latin American economies. Review of Development Economics, 18(4), 778-793.

Inequality Org. (2017). Facts. Retrieve from https://inequality.org/facts/income-inequality/

International Labour Organization. (2015). Global wage report 2014/15. Retrieved from http://ilo.org/global/publications/books/WCMS_324678/lang--en/index.htm

International Monetary Fund. (2016). World economic outlook. Retrieved from https://www.imf.org/en/Data

Jefferson, G. H., Huamao, B., Xiaojing, G., \& Xiaoyun, Y. (2006). R\&D performance in Chinese industry. Economics of Innovation and New Technology, 15(4-5), 345-366.

Kakwani, N. (1981). Welfare measures: An international comparison. Journal of Development Economics, 8(1), 21-45. 
Kokko, A., Tansini, R., \& Zejan, M. C. (1996). Local technological capability and productivity spillovers from FDI in the Uruguayan manufacturing sector. The Journal of Development Studies, 32(4), 602-611.

Kosack, S., \& Tobin, J. (2006). Funding self-sustaining development: The role of aid, FDI and government in economic success. International Organization, 60(01), 205-243.

Kottaridi, C., \& Stengos, T. (2010). Foreign direct investment, human capital and non-linearities in economic growth. Journal of Macroeconomics, 32(3), 858-871.

Kwok, C. C., \& Tadesse, S. (2006). The MNC as an agent of change for host-country institutions: FDI and corruption. Journal of International Business Studies, 37(6), 767-785.

Lehnert, K., Benmamoun, M., \& Zhao, H. (2013). FDI Inflow and human development: Analysis of FDI's impact on host countries' social welfare and infrastructure. Thunderbird International Business Review, 55(3), 285-298.

Liu, X., Siler, P., Wang, C., \& Wei, Y. (2000). Productivity spillovers from foreign direct investment: Evidence from UK industry level panel data. Journal of International Business Studies, 31(3), 407-425.

Liu, Z. (2008). Foreign direct investment and technology spillovers: Theory and evidence. Journal of Development Economics, 85(1), 176-193.

Mair, J., Martí, I., \& Ventresca, M. J. (2012). Building inclusive markets in rural Bangladesh: How intermediaries work institutional voids. Academy of Management Journal, 55(4), 819-850.

Marcin, K. (2008). How does FDI inflow affect productivity of domestic firms? The role of horizontal and vertical spillovers, absorptive capacity and competition. The Journal of International Trade \& Economic Development, 17(1), 155-173. 
Mayer, S. E. (2000). Income Inequality, economic segregation and children's educational attainment. Chicago, IL: Irving B. Harris Graduate School of Public Policy Studies, University of Chicago.

Melamed, C., \& Samman, E. (2013). Equity, inequality and human development in a post-2015 framework. New York, NY: UNDP, Human Development Report Office.

Meyer, K. E., \& Sinani, E. (2009). When and where does foreign direct investment generate positive spillovers? A meta-analysis. Journal of International Business Studies, 40(7), $1075-1094$.

Organization for Economic Cooperation and Development. (2014). Focus on inequality and growth-December 2014. Retrieved from http://www.oecd.org/social/inequality-andpoverty.htm

Ostry, J. D., \& Berg, A. (2011). Inequality and unsustainable growth; two sides of the same coin? Retrieved from http://www.imf.org/en/Publications/Staff-DiscussionNotes/Issues/2016/12/31/Inequality-and-Unsustainable-Growth-Two-Sides-of-the-SameCoin-24686

Pan-Long, T. (1995). Foreign direct investment and income inequality: Further evidence. World Development, 23(3), 469-483.

Perri, A., \& Peruffo, E. (2016). Knowledge spillovers from FDI: a critical review from the international business perspective. International Journal of Management Reviews, 18(1), 327.

Ranis, G., Stewart, F., \& Ramirez, A. (2000). Economic growth and human development. World Development, 28(2), 197-219.

Ranjan, V., \& Agrawal, G. (2011). FDI inflow determinants in BRIC countries: A panel data analysis. International Business Research, 4(4), 255-263. 
Reiter, S. L., \& Steensma, H. K. (2010). Human development and foreign direct investment in developing countries: The influence of FDI policy and corruption. World Development, 38(12), 1678-1691.

Rodrik, D. (2008). One economics, many recipes: Globalization, institutions, and economic growth. Princeton, NJ: Princeton University Press.

Sánchez-Sellero, P., Rosell-Martínez, J., \& García-Vázquez, J. M. (2014). Absorptive capacity from foreign direct investment in Spanish manufacturing firms. International Business Review, 23, 429-439.

Sen, A. (1999). Development as freedom. Oxford, England: Oxford Paperbacks.

Sen, S., \& Bhattacharya, C. B. (2001). Does doing good always lead to doing better? Consumer reactions to corporate social responsibility. Journal of Marketing Research, 38(2), 225-243.

Sharma, B., \& Gani, A. (2004). The effects of foreign direct investment on human development. Global Economy Journal, 4(2), 1-17.

Smarzynska Javorcik, B. (2004). Does foreign direct investment increase the productivity of domestic firms? In search of spillovers through backward linkages. The American Economic Review, 94(3), 605-627.

Spender, D. (2013). The education papers (Vol. 1). Oxford, England: Routledge.

Stephan, U., Uhlaner, L. M., \& Stride, C. (2015). Institutions and social entrepreneurship: The role of institutional voids, institutional support, and institutional configurations. Journal of International Business Studies, 46(3), 308-331.

Stewart, F., \& Samman, E. (2014). Inequality and development: An overview. 
Stiglitz, J. E. (2006). Stability with growth: Macroeconomics, liberalization and development. Oxford, England: Oxford University Press on Demand.

Streeten, P. (1999). Components of a future development strategy: The importance of human development. Finance and Development, 36(4), 30-33.

Subramanian, S., \& Kawachi, I. (2004). Income inequality and health: What have we learned so far? Epidemiologic Reviews, 26(1), 78-91.

Taylor, K., \& Driffield, N. (2005). Wage inequality and the role of multinationals: Evidence from UK panel data. Labour Economics, 12(2), 223-249.

Thimann, M. C., \& Dayal-Gulati, M. A. (1997). Saving in Southeast Asia and Latin America compared: Searching for policy lessons. International Monetary Fund.

Tian, X. (2007). Accounting for sources of FDI technology spillovers: Evidence from China. Journal of International Business Studies, 38(1), 147-159.

United Nations Conference on Trade and Development. (2016). UNCTAD. Retrieved from http://unctadstat.unctad.org/wds/ReportFolders/reportFolders.aspx?sCS_ChosenLang=en

United Nations Conference on Trade and Development. (2017). UNCTAD World Investment Report 2017. Retrieved from http://unctad.org/en/PublicationsLibrary/wir2017_en.pdf

United Nations Development Programme. (2015a). Human development data. Retrieved from http://hdr.undp.org/en/data

United Nations Development Programme. (2015b). Human development report 2015. Retrieved from http://hdr.undp.org/sites/default/files/2015_human_development_report.pdf

Walz, U. (1997). Innovation, foreign direct investment and growth. Economica, 64(253), 63-79. 
Wang, D. T., Gu, F. F., Tse, D. K., \& Yim, C. K. (2013). When does FDI matter? The roles of local institutions and ethnic origins of FDI. International Business Review, 22, 450-465.

Webb, J. W., Tihanyi, L., Ireland, R. D., \& Sirmon, D. G. (2009). You say illegal, I say legitimate: Entrepreneurship in the informal economy. Academy of Management Review, 34(3), 492510.

Wei, Y., \& Liu, X. (2006). Productivity spillovers from R\&D, exports and FDI in China's manufacturing sector. Journal of International Business Studies, 37(4), 544-557.

Wilkinson, R. G., \& Pickett, K. E. (2006). Income inequality and population health: A review and explanation of the evidence. Social Science \& Medicine, 62(7), 1768-1784.

World Bank. (2016). World development indicators. Retrieved from http://data.worldbank.org/datacatalog/world-development-indicators

World Commission on the Social Dimension of Globalization. (2004). A fair globalization:

Creating opportunities for all. International Labour Organization. Geneva, Switzerland.

World Economic Forum. (2015). The global competitiveness report 2015-2016. Retrieved from http://www3.weforum.org/docs/gcr/2015-2016/Global_Competitiveness_Report_20152016.pdf

World Economic Forum. (2016). Global competiveness data. Retrieve from http://reports.weforum.org/global-competitiveness-index/competitiveness-rankings/

Zhang, Y. A., Li, Y., \& Li, H. (2014). FDI spillovers over time in an emerging market: The roles of entry tenure and barriers to imitation. Academy of Management Journal, 57(3), 698-722.

Zhang, Y., Li, H., Li, Y., \& Zhou, L. A. (2010). FDI spillovers in an emerging market: The role of foreign firms' country origin diversity and domestic firms' absorptive capacity. Strategic 
Management Journal, 31(9), 969-989. 


\section{TABLES AND FIGURES}

\section{Tables analysis I}

Table 1 Correlations matrix and descriptive analytics

\section{(1)}

Mean Standard Human Deviation
(2)

Inward FDI stock
(3)

usines Soph.
(4)

Transparency

(1) Human

development

(2) Inward FDI stock

0.540

1.331

(3) Business

sophistication

3.485

(4) Transparency

(5) Foreign aid

(6) Trade openness

(7) Government savings

(8) Government

expenditure

(9) Gross Domestic Product (GDP)

Note:

a) See the variance inflation factor analysis in Table 8

b) $* p<0.05, * * p<0.01, * * * p<0.001$

c) The sample is an unbalanced panel data that includes up to 139 countries over a period of 14 years
0.100

$\begin{array}{rrr}1 & - & - \\ 0.135^{*} & 1 & - \\ 0.11 & 0.565^{* * *} & 1 \\ 0.104 & 0.212^{* *} & 0.094 \\ -0.136^{*} & 0.347^{* * *} & 0.293^{* * *} \\ 0.392^{* * *} & -0.0697 & -0.184^{* *} \\ 0.324^{* * *} & 0.302^{* * *} & 0.168^{*} \\ 0.0774 & 0.936^{* * *} & 0.564^{* * *} \\ 0.0777 & 0.939^{* * *} & 0.571^{* * *}\end{array}$

0.392

0.505

11.313

23.333

22.123
(5)

Foreign

aid

(6)

Trade

openness

(7)

(8)

Gov.

Gov.

expenditure 
Table 2 Fixed effects analysis: FDI stock effects and the moderation effect of institutions

\begin{tabular}{|c|c|c|c|c|c|c|c|c|}
\hline \multirow[b]{2}{*}{$\begin{array}{l}\text { Dependent variable: } \\
\text { human development }\end{array}$} & \multicolumn{2}{|c|}{ Controls } & \multicolumn{2}{|c|}{ Main effects } & \multicolumn{2}{|c|}{$\begin{array}{c}\text { Moderation- } \\
\text { business } \\
\text { sophistication }\end{array}$} & \multicolumn{2}{|c|}{$\begin{array}{l}\text { Moderation- } \\
\text { transparency }\end{array}$} \\
\hline & \multicolumn{2}{|c|}{ (1) } & \multicolumn{2}{|c|}{ (2) } & \multicolumn{2}{|c|}{ (3) } & \multicolumn{2}{|c|}{ (4) } \\
\hline \multicolumn{9}{|l|}{ Main variables } \\
\hline Inward FDI stock & - & & 0.005 & $* * *$ & 0.019 & $* * *$ & 0.109 & $* * *$ \\
\hline Inward FDI stock squared & - & & -0.000 & $* * *$ & -0.000 & $* *$ & -0.011 & $* * *$ \\
\hline Business sophistication & - & & - & & 0.024 & $* * *$ & - & \\
\hline Transparency & - & & - & & - & & 0.012 & $* *$ \\
\hline \multicolumn{9}{|l|}{ Interaction terms } \\
\hline $\begin{array}{l}\text { Inward FDI stock x Bus } \\
\text { sophistication } \\
\text { Inward FDI stock sq x }\end{array}$ & - & & - & & -0.004 & $* * *$ & - & \\
\hline $\begin{array}{l}\text { Bus sophistication } \\
\text { Inward FDI stock } \mathrm{x}\end{array}$ & - & & - & & 0.000 & $* *$ & - & \\
\hline $\begin{array}{l}\text { Transparency } \\
\text { Inward FDI stock sq x }\end{array}$ & - & & - & & - & & -0.028 & $* * *$ \\
\hline Transparency & - & & - & & - & & 0.003 & $* * *$ \\
\hline \multicolumn{9}{|l|}{ Controls } \\
\hline$\overline{\text { Foreign aid }}$ & 0.126 & $* * *$ & 0.066 & $* * *$ & 0.019 & $*$ & 0.022 & \\
\hline Trade openness & 0.001 & $* * *$ & 0.000 & $* *$ & 0.000 & & 0.000 & \\
\hline Government savings & 0.001 & $* * *$ & 0.001 & $* * *$ & -0.000 & $* *$ & -0.000 & \\
\hline Government expenditure & 0.005 & $* * *$ & 0.000 & & -0.000 & & -0.001 & \\
\hline GDP & -0.003 & $* * *$ & -0.000 & & 0.000 & & 0.004 & \\
\hline Constant & 0.513 & $* * *$ & 0.574 & $* * *$ & 0.532 & $* * *$ & 0.453 & $* * *$ \\
\hline Observations & 1,040 & & 916 & & 512 & & 351 & \\
\hline Country No & 131 & & 130 & & 82 & & 60 & \\
\hline Fixed effects & Incl. & & Incl. & & Incl. & & Incl. & \\
\hline R-squared (within) & 0.286 & & 0.300 & & 0.381 & & 0.320 & \\
\hline
\end{tabular}

Note:
a) $* \mathrm{p}<0.05, * * \mathrm{p}<0.01, * * * \mathrm{p}<0.001$
b) All independent and control variables were included with a one-year lag
c) The sample is an unbalanced panel data that includes up to 139 countries over a period of 14 years which explains the different observations in each model
d) The fixed effects accounts for time-invariant factors that exhibit systematic variations across countries 
Table 3 Inverted $U$ analysis: Testing inverted $U$-shaped relationships of main effects and moderations (Haans et al., 2016)

Main effects

Dependent variable: human development

Slope:

Inward FDI stock

Slope at lowest point

Slope at the highest point

(1)
Moderationbusiness sophistication

$\begin{aligned} 0.005 & \\ (11.58) & * * * \\ -0.004 & \\ (-7.131) & * * *\end{aligned}$

0.019

(5.99)

$-0.021$

$(-2.145)$

39.253

(2.15)

5.076

48.354

(7.13)

$* * *$

0.000

83.288
(2)
0.000

83.288

0.109

$-0.378$
(3)

Moderationtransparency

90\% confidence interval:

Lower level

Upper level

(5.944) ***

$(-3.298) \quad * * *$

Note:
a) $* \mathrm{p}<0.05, * * \mathrm{p}<0.01, * * * \mathrm{p}<0.001$
b) All independent and control variables were included with a one-year lag
c) t-values are in parentheses
d) The sample is an unbalanced panel data that includes up to 139 countries over a period of 14 years 
Table 4 Robustness test: Nonlinear effects of FDI inflows and inward FDI stock/GDP

on human development

FDI inflows

development

\section{Main variables}

FDI inflows

FDI inflows squared

Inward FDI stock/GDP

Inward FDI FDI stock/GDP squared

\section{Controls}

Foreign aid

Trade openness

Government savings

Government expenditure

GDP

Constant

Observations

Country No

Fixed effects

R-squared (within)

Inward FDI stock/GDP

(1)
$0.026 * * *$

$-0.003 * * *$

$-$

$-$
(2)

***

$-0.000 * * *$

$\begin{array}{rl}0.069 & * * * \\ 0.000 & * \\ 0.000 & * * \\ -0.000 & \\ 0.001 & \end{array}$

$0.063 * * *$

$0.000 * *$

$0.001 * * *$

$0.002 * * *$

$-0.001 * *$

$0.577 * * *$

904

$0.544 * * *$

915

129

Included

0.284

Note:

a) $* \mathrm{p}<0.05, * * \mathrm{p}<0.01,{ }^{* * *} \mathrm{p}<0.001$

b) All independent and control variables were included with a one-year lag

c) The sample is an unbalanced panel data that includes up to 139 countries over a period of 14 years which explains the different observations in each model

d) The fixed effects accounts for time-invariant factors that exhibit systematic variations across countries 


\section{Table 5 Robustness test: Nonlinear effects of FDI on human development components}

\begin{tabular}{|c|c|c|c|c|c|c|c|c|c|c|c|c|c|c|c|c|c|c|}
\hline \multirow{4}{*}{$\begin{array}{l}\text { Dependent variable } \\
\text { Main variables }\end{array}$} & \multicolumn{6}{|c|}{ Inward FDI Stock } & \multicolumn{6}{|c|}{ FDI Inflows } & \multicolumn{6}{|c|}{ Inward FDI Stock/GDP } \\
\hline & \multicolumn{2}{|c|}{ (1) } & \multicolumn{2}{|c|}{ (2) } & \multicolumn{2}{|l|}{ (3) } & \multicolumn{2}{|c|}{ (4) } & \multicolumn{2}{|c|}{ (5) } & \multicolumn{2}{|l|}{ (6) } & \multicolumn{2}{|c|}{ (7) } & \multicolumn{2}{|c|}{ (8) } & \multicolumn{2}{|l|}{ (9) } \\
\hline & \multicolumn{2}{|c|}{$\begin{array}{l}\text { Education } \\
\text { index }\end{array}$} & \multicolumn{2}{|c|}{ Health index } & \multicolumn{2}{|c|}{ GNI per capita } & \multicolumn{2}{|c|}{$\begin{array}{l}\text { Education } \\
\quad \text { index }\end{array}$} & \multicolumn{2}{|c|}{ Health index } & \multicolumn{2}{|c|}{ GNI per capita } & \multicolumn{2}{|c|}{$\begin{array}{l}\text { Education } \\
\text { index }\end{array}$} & \multicolumn{2}{|c|}{ Health index } & \multicolumn{2}{|c|}{ GNI per capita } \\
\hline & & & & & & & & & & & & & & & & & & \\
\hline Inward FDI stock & 0.010 & $* * *$ & 0.004 & $* * *$ & 368.147 & $* * *$ & - & & - & & - & & - & & - & & - & \\
\hline Inward FDI stock squared & -0.000 & $* * *$ & -0.000 & $* * *$ & -3.348 & $* * *$ & - & & - & & - & & - & & - & & - & \\
\hline FDI inflows & - & & - & & - & & 0.058 & $* * *$ & 0.019 & $* * *$ & $1,902.599$ & $* * *$ & - & & - & & - & \\
\hline FDI inflows squared & - & & - & & - & & -0.007 & $* * *$ & -0.002 & $* * *$ & -195.703 & $* * *$ & - & & - & & - & \\
\hline Inward FDI stock/GDP & - & & - & & - & & - & & - & & - & & 0.003 & $* * *$ & 0.001 & $* * *$ & 63.725 & $* * *$ \\
\hline Inward FDI stock/GDP squared & - & & - & & - & & - & & - & & - & & -0.000 & $* * *$ & -0.000 & $* * *$ & -0.410 & $* * *$ \\
\hline \multicolumn{19}{|l|}{ Controls } \\
\hline Foreign aid & 0.294 & $* * *$ & 0.059 & $* *$ & 579.700 & & 0.299 & $* * *$ & 0.062 & $* *$ & 625.220 & & 0.220 & $* * *$ & 0.060 & $* *$ & 964.432 & \\
\hline Trade openness & 0.001 & $* * *$ & 0.000 & $* *$ & -15.436 & $* * *$ & 0.001 & $* * *$ & 0.000 & $*$ & -16.574 & $* * *$ & 0.000 & $* *$ & 0.000 & $* *$ & -14.498 & $* * *$ \\
\hline Government savings & 0.001 & $* *$ & 0.000 & $*$ & 43.175 & $* * *$ & 0.001 & & 0.000 & & 38.674 & $* * *$ & 0.001 & $* *$ & 0.000 & $*$ & 46.951 & $* * *$ \\
\hline Government expenditure & -0.002 & & 0.000 & & -51.695 & & -0.004 & $*$ & 0.000 & & -44.136 & & 0.005 & $* *$ & 0.002 & $*$ & 126.737 & $* * *$ \\
\hline GDP & 0.002 & & -0.000 & & 57.757 & & 0.005 & $* *$ & 0.001 & & 101.929 & $*$ & -0.004 & $* *$ & -0.001 & * & -83.685 & $*$ \\
\hline Constant & 0.456 & $* * *$ & 0.681 & $* * *$ & $7,797.103$ & $* * *$ & 0.450 & $* * *$ & 0.683 & $* * *$ & $7,880.254$ & $* * *$ & 0.414 & $* * *$ & 0.656 & $* * *$ & $6,817.016$ & $* * *$ \\
\hline Observations & 623 & & 913 & & 939 & & 611 & & 901 & & 927 & & 623 & & 912 & & 938 & \\
\hline Country No & 115 & & 137 & & 137 & & 115 & & 135 & & 135 & & 115 & & 136 & & 136 & \\
\hline Fixed effects & Incl. & & Incl. & & Incl. & & Incl. & & Incl. & & Incl. & & Incl. & & Incl. & & Incl. & \\
\hline R-squared (within) & 0.392 & & 0.122 & & 0.315 & & 0.354 & & 0.096 & & 0.233 & & 0.451 & & 0.136 & & 0.206 & \\
\hline \multicolumn{19}{|l|}{ Note: } \\
\hline a) $* \mathrm{p}<0.05, * * \mathrm{p}<0.01, * * * \mathrm{p}<0$ & & & & & & & & & & & & & & & & & & \\
\hline b) All independent and control v & les were & & 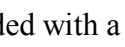 & & & & & & & & & & & & & & & \\
\hline ) $=1$ & data tha & & & & & & & & & & & & & & & & & \\
\hline
\end{tabular}


Table 6 Robustness test: Moderation effect of institutions on the relationship between

\section{FDI inflows, inward FDI stock/GDP and human development}

Dependent variable: human development

Main variables

FDI inflows

FDI inflows squared

Inward FDI stock/GDP

Inward FDI stock/GDP squared

Business Sophistication

Transparency

Interaction terms

FDI inflows $\mathrm{x}$ Bus sophistication

FDI inflows sq $x$ Bus sophistication

FDI inflows $x$ Transparency

FDI inflows sq x Transparency

Inward FDI stock/GDP x Bus

Sophistication

Inward FDI stock/GDP sq x Bus

Sophistication

Inward FDI stock/GDP x Transparency

Inward FDI stock/GDP sq x Transparency

\section{Controls}

Foreign aid

Trade openness

Government savings

Government expenditures

GDP

Constant

Observations

Country No

Fixed effects

R-squared (within)
Note:

a) $*$ p $<0.05, * * \mathrm{p}<0.01, * * * \mathrm{p}<0.001$

b) All independent and control variables were included with a one-year lag

c) The sample is an unbalanced panel data that includes up to 139 countries over a period of 14 years

d) The fixed effects accounts for time-invariant factors that exhibit systematic variations across countries
FDI inflows

(1)

(2)
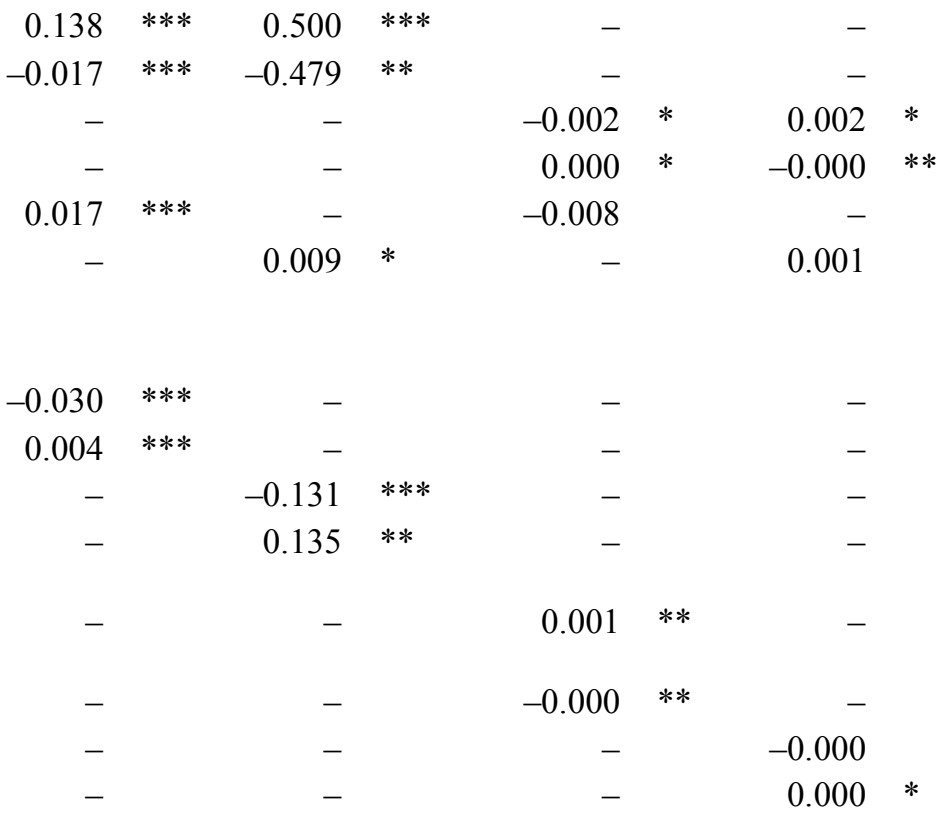

Inward FDI stock/GDP

(3)

(4)

$\begin{array}{rrrl}- & - & \\ - & & - & \\ -0.002 & * & 0.002 & * \\ 0.000 & * & -0.000 & * * \\ -0.008 & & - & \\ - & & 0.001 & \end{array}$

\begin{tabular}{|c|c|c|c|c|c|c|}
\hline 0.020 & & 0.012 & & 0.020 & & 0.007 \\
\hline-0.000 & & 0.000 & & 0.000 & & 0.000 \\
\hline-0.001 & $* * *$ & -0.000 & & -0.000 & $* *$ & -0.000 \\
\hline-0.000 & & -0.003 & & 0.001 & & -0.002 \\
\hline 0.001 & & 0.004 & & -0.001 & & 0.003 \\
\hline 0.571 & $* * *$ & 0.479 & $* * *$ & 0.646 & $* * *$ & 0.477 \\
\hline 507 & & 344 & & 512 & & 350 \\
\hline 82 & & 59 & & 82 & & 59 \\
\hline Incl. & & Incl. & & Incl. & & Incl. \\
\hline 0.2680 & & 0.2327 & & 0.2447 & & 0.1991 \\
\hline
\end{tabular}


Table 7 Robustness test: Inverted U analysis of inward FDI stock, FDI inflows and inward FDI stock/GDP on HDI components

\section{Inward FDI Stock}

(1)

Education index
(3)

Health index
GNI per capita
(4)

Human development

\section{FDI Inflows}

(5)

Education index Health index

GNI per capita

\section{Slope:}

Inward FDI stock

Slope at lowest point

$\begin{aligned} 0.010 & & 0.004 & & 368.147 & \\ (10.089) & * * * & (6.685) & * * * & (13.797) & * * * \\ -0.006 & & -0.003 & & -189.595 & \\ (-5.356) & * * * & (-3.574) & * * * & (-6.048) & * * *\end{aligned}$

Slope at the highest point

FDI inflows

Slope at lowest point

Slope at the highest point

\section{Appropriate Inverted U test:}

Extremum point

\begin{tabular}{|c|c|c|c|c|}
\hline 49.648 & & 50.630 & & 54.976 \\
\hline$(5.36)$ & $* * *$ & $(3.57)$ & $* * *$ & $(6.05)$ \\
\hline 0.001 & & 0.000 & & 0.000 \\
\hline 83.288 & & 83.288 & & 83.288 \\
\hline
\end{tabular}

-
-
-

$$
0.026
$$

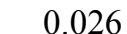

(7.243) ***

$-0.054$

$$
\begin{array}{r}
-0.054 \\
(-6.424)
\end{array}
$$

$* * *$

0.058

\subsection{3}

(6.42) *

90\% confidence interval:

Lower level

83.288

83.288

0.000

12.399

(6.895)

$-0.105$

$(-5.405)$

4.439

(5.4) *

0.000

12.399

$\begin{array}{rrrr}0.019 & & 1,902.598 & \\ (4.372) & * * * & (9.037) & * * * \\ -0.038 & & -2,950.238 & \\ (-3.489) & * * * & (-5.903) & * * * \\ & & & \\ 4.166 & & 4.861 & \\ (3.49) & * * * & (5.9) & * * * \\ & & & \\ 0.000 & & 0.000 & \\ 12.399 & & 12.399 & \end{array}$

Note:

a) $* \mathrm{p}<0.05, * * \mathrm{p}<0.01, * * * \mathrm{p}<0.001$

b) All independent and control variables were included with a one-year lag

c) t-values are in parentheses

d) The sample is an unbalanced panel data that includes up to 139 countries over a period of 14 years 
Moderation effects

\begin{tabular}{|c|c|c|c|c|c|c|c|c|c|c|c|c|}
\hline & Mod & erati & effects & & & & & & & & & \\
\hline & $\begin{array}{c}\text { FDI inflows } \\
\text { bus. } \\
\text { sophisticati }\end{array}$ & & $\begin{array}{c}\text { FDI inflo } \\
\text { and } \\
\text { transpare }\end{array}$ & & & & Inwarc & FD & stock/GDI & & & \\
\hline & (8) & & (9) & & (10) & & (11) & & (12) & & (13) & \\
\hline Dependent variable: & $\begin{array}{c}\text { Human } \\
\text { developme }\end{array}$ & & $\begin{array}{r}\text { Human } \\
\text { developme }\end{array}$ & & $\begin{array}{r}\text { Humar } \\
\text { developm }\end{array}$ & & $\begin{array}{r}\text { Educati } \\
\text { index }\end{array}$ & & Health in & dex & $\begin{array}{l}\text { GNI pe } \\
\text { capita }\end{array}$ & \\
\hline Slope: & & & & & & & & & & & & \\
\hline FDI inflows & & & & & & & & & & & & \\
\hline Slope at lowest point & 0.138 & & 0.500 & & - & & - & & - & & - & \\
\hline & $(6.447)$ & $* * *$ & $(4.583)$ & $* * *$ & - & & - & & - & & - & \\
\hline Slope at the highest point & $\begin{array}{r}-0.281 \\
(-5.327)\end{array}$ & $* * *$ & $\begin{array}{r}-4.015 \\
(-2.987)\end{array}$ & $* *$ & $\begin{array}{l}- \\
-\end{array}$ & & - & & - & & - & \\
\hline Inward FDI stock/GDP & & & & & & & & & & & & \\
\hline Slope at lowest point & - & & - & & 0.002 & & 0.003 & & 0.001 & & 63.679 & \\
\hline & - & & - & & $(11.002)$ & $* * *$ & $(12.382)$ & $* * *$ & $(7.662)$ & $* * *$ & $(7.303)$ & $* * *$ \\
\hline Slope at the highest point & - & & - & & $\begin{array}{l}-0.002 \\
(-7.31)\end{array}$ & $* * *$ & $\begin{array}{r}-0.003 \\
(-5.519)\end{array}$ & $* * *$ & $\begin{array}{r}-0.002 \\
(-5.598)\end{array}$ & $* * *$ & $\begin{array}{l}-91.222 \\
(-4.642)\end{array}$ & *** \\
\hline Appropriated inverted U & & & & & & & & & & & & \\
\hline Extremum point & $\begin{array}{l}4.081 \\
(5.33)\end{array}$ & $* * *$ & $\begin{array}{l}0.522 \\
(2.99)\end{array}$ & $* *$ & $\begin{array}{r}75.494 \\
(7.31)\end{array}$ & $* * *$ & $\begin{array}{r}93.362 \\
(5.52)\end{array}$ & $* * *$ & $\begin{array}{r}71.707 \\
(5.6)\end{array}$ & $* * *$ & $\begin{array}{r}77.787 \\
(4.64)\end{array}$ & $* * *$ \\
\hline $90 \%$ confidence interval & & & & & & & & & & & & \\
\hline Lower level & 0.000 & & 0.000 & & 0.056 & & 0.285 & & 0.056 & & 0.056 & \\
\hline Upper level & 12.399 & & 4.710 & & 189.137 & & 189.137 & & 189.137 & & 189.137 & \\
\hline
\end{tabular}


Table 8 Robustness test: Multicollinearity test diagnostics

\begin{tabular}{|c|c|c|c|c|c|}
\hline & Variable & $\begin{array}{c}\text { Variance } \\
\text { Inflation } \\
\text { Factor } \\
\text { (VIF) }\end{array}$ & VIF Squared & Tolerance & $\begin{array}{c}\text { R - } \\
\text { Squared }\end{array}$ \\
\hline (1) & Human development & 1.36 & 1.17 & 0.734 & 0.266 \\
\hline (2) & Inward FDI stock & 10.93 & 3.31 & 0.092 & 0.909 \\
\hline (3) & Business sophistication & 1.64 & 1.28 & 0.61 & 0.39 \\
\hline (4) & Transparency & 1.17 & 1.08 & 0.853 & 0.147 \\
\hline (5) & Foreign aid & 1.33 & 1.15 & 0.751 & 0.249 \\
\hline (6) & Trade openness & 1.48 & 1.22 & 0.676 & 0.324 \\
\hline (7) & Government savings & 1.47 & 1.21 & 0.68 & 0.321 \\
\hline (8) & Government expenditures & 1073.08 & 32.76 & 0.001 & 0.999 \\
\hline \multirow[t]{2}{*}{ (9) } & GDP & 1129.96 & 33.61 & 0.001 & 0.999 \\
\hline & Mean VIF & 246.94 & & & \\
\hline
\end{tabular}

Eigenval

$\begin{array}{cc}\mathbf{1} & 6.715 \\ \mathbf{2} & 2.369 \\ \mathbf{3} & 0.511 \\ \mathbf{4} & 0.175 \\ \mathbf{5} & 0.133 \\ \mathbf{6} & 0.053 \\ \mathbf{7} & 0.025 \\ \mathbf{8} & 0.015 \\ \mathbf{9} & 0.004 \\ \mathbf{1 0} & 0.000\end{array}$

Condition Number

Eigenvalues \& Cond Index computed from scaled raw $\operatorname{sscp}(\mathrm{w} /$ intercept)

Det (correlation matrix)

\section{Condition Index}

$$
\begin{array}{r}
1.000 \\
1.684 \\
3.627 \\
6.189 \\
7.114 \\
11.282 \\
16.335 \\
20.904 \\
43.323 \\
126.742
\end{array}
$$

126.742 


\section{Tables analysis II}

\section{Table 1 Correlations matrix and descriptive analytics}

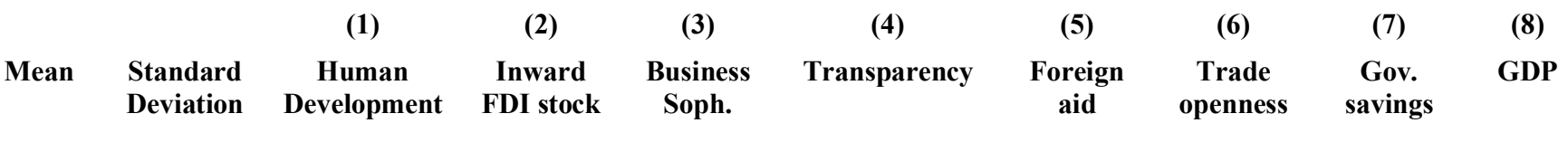

(1) Human $\begin{array}{lll}\text { development } & 0.548 & 0.105\end{array}$

(2) Inward FDI stock $\quad 1.236 \quad 3.21$

(3) Business $\begin{array}{lll}\text { sophistication } & 3.496 & 0.394\end{array}$

(4) Transparency $\quad 2.91 \quad 0.503$

(5) Foreign aid $\quad 0.076 \quad 0.087$

(6) Trade openness $\quad 79.088 \quad 34.507$

(7) Government

savings

$19.481 \quad 11.008$

$0.124 * \quad 0.197 * *$
$0.124 * \quad 0.197 * * \quad 0.0879$

$-0.185 * * \quad 0.343 * * * \quad 0.238 * * *$

$0.368 * * *-0.0777-0.166 * *$

Product (GDP)

5.867

20.864

$\begin{array}{rrr}0.231 * * * & 0.304 * * * & 0.152 * \\ 0.052 & 0.939 * * * & 0.529 * * *\end{array}$

0.0762

$-0.000439-0.216^{* * *}$

$0.324 * * * \quad 0.165 * *$

0.102

$0.196 * * \quad 0.267 * * *$

$-0.184 * * \quad 0.260 * * *$

Note:

a) See the variance inflation factor analysis in Table 8

b) $* \mathrm{p}<0.05, * * \mathrm{p}<0.01, * * * \mathrm{p}<0.001$

c) The sample is an unbalanced panel data that includes up to 139 countries over a period of 14 years 
Table 2 Fixed effects analysis: FDI stock effects and the moderation effect of institutions

\begin{tabular}{|c|c|c|c|c|c|c|c|c|}
\hline \multirow[b]{2}{*}{$\begin{array}{l}\text { Dependent variable: } \\
\text { human development }\end{array}$} & \multicolumn{2}{|c|}{ Controls } & \multicolumn{2}{|c|}{ Main effects } & \multicolumn{2}{|c|}{$\begin{array}{l}\text { Moderation- } \\
\text { business } \\
\text { sophistication }\end{array}$} & \multicolumn{2}{|c|}{$\begin{array}{l}\text { Moderation- } \\
\text { transparency }\end{array}$} \\
\hline & (1) & & (2) & & (3) & & (4) & \\
\hline \multicolumn{9}{|l|}{ Main variables } \\
\hline Inward FDI stock & - & & 0.006 & $* * *$ & 0.019 & $* * *$ & 0.095 & $* * *$ \\
\hline Inward FDI stock squared & - & & -0.000 & $* * *$ & -0.000 & $* * *$ & -0.010 & $* * *$ \\
\hline Business sophistication & - & & - & & 0.023 & $* * *$ & - & \\
\hline Transparency & - & & - & & - & & 0.009 & $* *$ \\
\hline \multicolumn{9}{|l|}{ Interaction terms } \\
\hline $\begin{array}{l}\text { Inward FDI stock x Bus } \\
\text { sophistication } \\
\text { Inward FDI stock sq x }\end{array}$ & - & & - & & -0.004 & $* * *$ & - & \\
\hline $\begin{array}{l}\text { Bus sophistication } \\
\text { Inward FDI stock x }\end{array}$ & - & & - & & 0.000 & $* *$ & - & \\
\hline $\begin{array}{l}\text { Transparency } \\
\text { Inward FDI stock sq x }\end{array}$ & - & & - & & - & & -0.023 & $* * *$ \\
\hline Transparency & - & & - & & - & & 0.003 & $* * *$ \\
\hline \multicolumn{9}{|l|}{ Controls } \\
\hline$\overline{\text { Foreign aid }}$ & 0.051 & $* *$ & 0.025 & $* *$ & 0.018 & $*$ & 0.036 & $* *$ \\
\hline Trade openness & 0.001 & $* * *$ & 0.000 & & 0.000 & & 0.000 & \\
\hline Government savings & 0.001 & $* * *$ & 0.001 & $* * *$ & -0.000 & $* *$ & -0.000 & \\
\hline GDP & 0.001 & $* * *$ & 0.000 & $* * *$ & 0.000 & $* * *$ & 0.003 & $* * *$ \\
\hline Constant & 0.523 & $* * *$ & 0.584 & $* * *$ & 0.539 & $* * *$ & 0.484 & $* * *$ \\
\hline Observations & 1,243 & & 1,081 & & 550 & & 444 & \\
\hline Country No & 140 & & 139 & & 90 & & 65 & \\
\hline Fixed effects & Included & & Included & & Included & & Included & \\
\hline R-squared (within) & 0.229 & & 0.266 & & 0.374 & & 0.311 & \\
\hline
\end{tabular}

Note:

a) $* \mathrm{p}<0.05, * * \mathrm{p}<0.01, * * * \mathrm{p}<0.001$

b) All independent and control variables were included with a one-year lag

c) The sample is an unbalanced panel data that includes up to 139 countries over a period of 14 years which explains the different observations in each model

d) The fixed effects accounts for time-invariant factors that exhibit systematic variations across countries 
Table 3 Inverted $U$ analysis: Testing inverted $U$-shaped relationships of main effects and moderations (Haans et al., 2016)

Main effects $\begin{gathered}\text { Moderation- } \\ \text { business } \\ \text { sophistication }\end{gathered}$

(1)

(2)

\section{Moderation- transparency}

(3)
Dependent variable: human development

Slope:

Inward FDI stock

Slope at lowest point

Slope at the highest point

Appropriate Inverted U test:

Extremum point

49.453

(7.54)

$\begin{aligned} 0.006 & \\ (13.941) & * * * \\ -0.004 & \\ (-7.538) & * * *\end{aligned}$

0.019

(6.276)

$-0.022$

$(-2.289)$

90\% confidence interval:

Lower level

0.000

0.000

0.000

Upper level

83.288

83.288

22.655

Note:
a) $* \mathrm{p}<0.05, * * \mathrm{p}<0.01, * * * \mathrm{p}<0.001$
b) All independent and control variables were included with a one-year lag
c) t-values are in parentheses
d) The sample is an unbalanced panel data that includes up to 139 countries over a period of 14 years 
Table 4 Robustness test: Nonlinear effects of FDI inflows and inward FDI stock/GDP

on human development

FDI inflows

development

Main variables

FDI inflows

FDI inflows squared

Inward FDI stock/GDP

Inward FDI FDI stock/GDP squared

\section{Controls}

Foreign aid

Trade openness

Government savings

GDP

Constant

Observations

Country No

Fixed effects

R-squared (within)

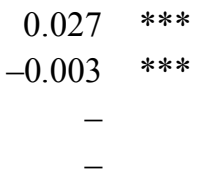

$0.027 * *$

0.000

$0.000 * *$

0.001

$* * *$

$0.587 \quad * * *$

1,067

138

Included

0.208
Inward FDI stock/GDP

(2)

Note:

a) $* \mathrm{p}<0.05, * * \mathrm{p}<0.01, * * * \mathrm{p}<0.001$

b) All independent and control variables were included with a one-year lag

c) The sample is an unbalanced panel data that includes up to 139 countries over a period of 14 years which explains the different observations in each model

d) The fixed effects accounts for time-invariant factors that exhibit systematic variations across countries 


\section{Table 5 Robustness test: Nonlinear effects of FDI on human development components}

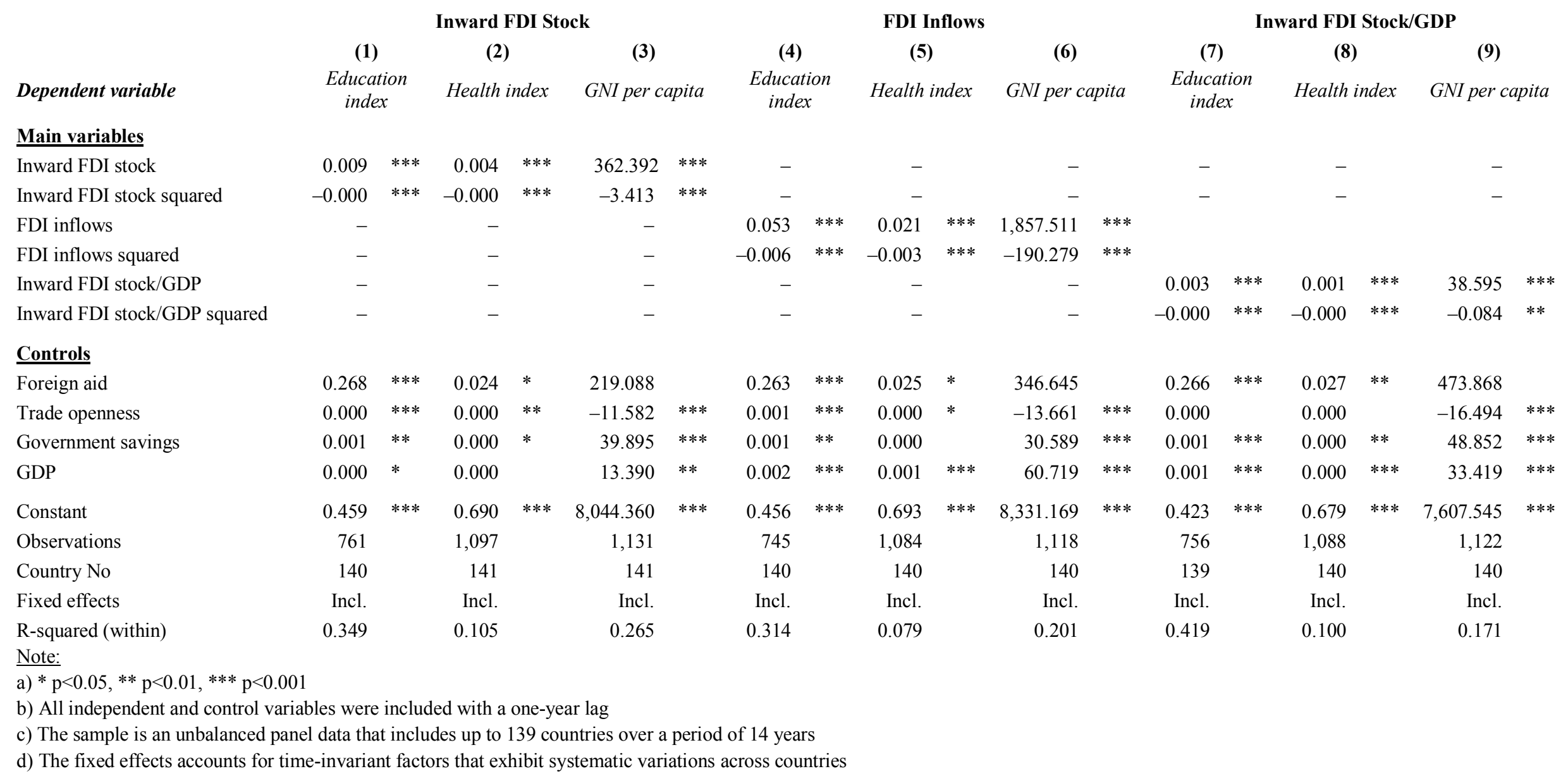


Table 6 Robustness test: Moderation effect of institutions on the relationship between

\section{FDI inflows, inward FDI stock/GDP and human development}

\section{FDI inflows}

Dependent variable: human development

Main variables

FDI inflows

FDI inflows squared

Inward FDI stock/GDP

Inward FDI stock/GDP squared

Business Sophistication

Transparency

\section{Interaction terms}

FDI inflows x Bus sophistication

FDI inflows sq $x$ Bus sophistication

FDI inflows $x$ Transparency

FDI inflows sq $x$ Transparency

Inward FDI stock/GDP x Bus

Sophistication

Inward FDI stock/GDP sq x Bus

Sophistication

Inward FDI stock/GDP x Transparency

Inward FDI stock/GDP sq x Transparency

\section{Controls}

Foreign aid

Trade openness

Government savings

GDP

Constant

Observations

Country No

Fixed effects

R-squared (within)
(1)

$\begin{array}{rrrr}0.137 & * * * & 0.403 & * * * \\ -0.017 & * * * & -0.430 & * * \\ - & & - & \\ - & & - & \\ 0.017 & * * * & - & \\ - & & 0.005 & \end{array}$

$-0.030 * * *$

$0.004 * * *$

$-\quad-0.098 * *$

$-\quad 0.120 * *$

$-$

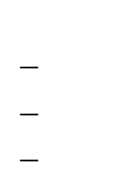

$\begin{array}{rr}0.019 & \\ -0.000 & \\ -0.001 & * * * \\ 0.001 & * * * \\ & \\ 0.575 & * * * \\ 545 & \\ 90 & \\ \text { Included } & \\ 0.261 & \end{array}$

(2)
Inward FDI stock/GDP

(3)

(4)

$\begin{array}{rrrl}- & & \\ - & - & \\ -0.002 & * & 0.001 & * \\ 0.000 & * & -0.000 & * * \\ -0.009 & & - & \\ - & -0.002 & \end{array}$

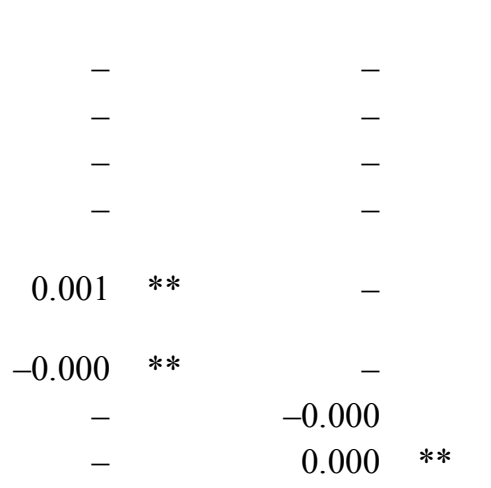

$\begin{array}{rlrl}0.027 & * & 0.020 & * \\ -0.000 & & -0.000 & \\ -0.000 & & -0.000 & * * \\ 0.001 & * & 0.000 & * * * \\ & & & \\ 0.514 & * * * & 0.650 & * * * \\ 437 & & 543 & \\ 65 & & 89 & \\ \text { Included } & \text { Included } & \\ 0.218 & 0.237 & \end{array}$

0.023

$-0.000$

$-0.000$

0.001

0.512 436

64

Included

0.181

Note:
a) $*$ p $<0.05, * * \mathrm{p}<0.01, * * * \mathrm{p}<0.001$
b) All independent and control variables were included with a one-year lag
c) The sample is an unbalanced panel data that includes up to 139 countries over a period of 14 years
d) The fixed effects accounts for time-invariant factors that exhibit systematic variations across countries 
Table 7 Robustness test: Inverted U analysis of inward FDI stock, FDI inflows and inward FDI stock/GDP on HDI components

\section{Inward FDI Stock}

(1)

(2)

(3)

Dependent variable:

Education index

Health index
(4)

Human development

\section{FDI Inflows}

(5)

(6)

(7)

Education index Health index

GNI per capita

\section{Slope:}

Inward FDI stock

Slope at lowest point

$\begin{aligned} 0.009 & & 0.004 & & 362.392 & \\ (11.624) & * * * & (8.259) & * * * & (14.436) & * * * \\ -0.007 & & -0.003 & & -206.186 & \\ (-5.633) & * * * & (-3.908) & * * * & (-6.483) & * * *\end{aligned}$

Slope at the highest point

FDI inflows

Slope at lowest point

Slope at the highest point

\section{Appropriate Inverted U test:}

Extremum point

$\begin{array}{rrrrr}48.288 & & 51.498 & & 53.085 \\ (5.63) & * * * & (3.91) & * * * & (6.48) \\ & & & & \\ 0.001 & & 0.000 & & 0.000 \\ 83.288 & & 83.288 & & 83.288\end{array}$

90\% confidence interval:

\section{Lower level}

83.288

83.288

83.288

$$
\begin{aligned}
& - \\
& - \\
& -
\end{aligned}
$$

$\begin{array}{rlrlrrrr}0.03 & & 0.053 & & 0.021 & & 1,857.510 & \\ (9.571) & * * * & (8.116) & * * * & (5.865) & * * * & (10.527) & * * * \\ -0.06 & & -0.093 & & -0.041 & & -2,860.832 & \\ (-7.43) & * * * & (-5.345) & * * * & (-4.243) & * * * & (-5.998) & * * *\end{array}$

Note:

a) $* \mathrm{p}<0.05, * * \mathrm{p}<0.01, * * * \mathrm{p}<0.001$

b) All independent and control variables were included with a one-year lag

c) t-values are in parentheses

d) The sample is an unbalanced panel data that includes up to 139 countries over a period of 14 years 
Moderation effects

$\begin{array}{ccc}\text { FDI inflows } & \text { FDI inflows } & \\ \text { and bus. } & \text { and } & \text { Inward FDI stock/GDP }\end{array}$

$\begin{array}{cc}\text { and bus. } & \text { and } \\ \text { sophistication } & \text { transparency }\end{array}$

Dependent variable:

Slope:

\section{FDI inflows}

Slope at lowest point

Slope at the highest point

Inward FDI stock/GDP

Slope at lowest point

Slope at the highest point

\section{Appropriated inverted $U$ test}

Extremum point

90\% confidence interval:

Lower level

Upper level
(8)

Human

development

(9)

Human

development

(10)

(11)

Human

development

Education

index

(12)

(13)

GNI per

capita

\begin{tabular}{|c|c|c|c|c|c|c|c|c|c|c|}
\hline 0.137 & & 0.403 & & - & & - & & - & & - \\
\hline (6.64) & $* * *$ & (4.173) & $* * *$ & - & & - & & - & & - \\
\hline-0.276 & & -3.646 & & - & & - & & - & & - \\
\hline$(-5.473)$ & $* * *$ & $(-2.976)$ & $* *$ & - & & - & & - & & - \\
\hline- & & - & & 0.001 & & 0.003 & & 0.001 & & 38.585 \\
\hline- & & - & & (10.84) & $* * *$ & (13.983) & $* * *$ & $(6.758)$ & $* * *$ & (6.884) \\
\hline- & & - & & -0.001 & & -0.002 & & -0.000 & & -3.802 \\
\hline - & & - & & $(-5.364)$ & $* * *$ & $(-4.553)$ & $* * *$ & $(-1.371)$ & & $(-0.484)$ \\
\hline $\begin{array}{l}4.081 \\
(5.47)\end{array}$ & $* * *$ & $\begin{array}{l}0.469 \\
(2.98)\end{array}$ & $* *$ & $\begin{array}{r}124.231 \\
(5.36)\end{array}$ & $* * *$ & $\begin{array}{r}151.451 \\
(4.55)\end{array}$ & $* * *$ & $\begin{array}{r}190.419 \\
(1.37)\end{array}$ & & $\begin{array}{r}230.203 \\
(0.48)\end{array}$ \\
\hline 0.000 & & 0.000 & & 0.056 & & 0.285 & & 0.056 & & 0.056 \\
\hline 12.399 & & 4.710 & & 252.879 & & 252.879 & & 248.558 & & 252.879 \\
\hline
\end{tabular}


Table 8 Robustness test: Multicollinearity test diagnostics

\begin{tabular}{llrrrr}
\multicolumn{1}{c}{ Variable } & $\begin{array}{c}\text { Variance } \\
\text { Inflation } \\
\text { Factor (VIF) }\end{array}$ & $\begin{array}{c}\text { VIF } \\
\text { Squared }\end{array}$ & Tolerance & R - Squared \\
(1) & Human development & 1.34 & 1.16 & 0.746 & 0.254 \\
$\mathbf{( 2 )}$ & Inward FDI stock & 10.59 & 3.25 & 0.095 & 0.906 \\
$\mathbf{( 3 )}$ & Business sophistication & 1.50 & 1.22 & 0.668 & 0.332 \\
$\mathbf{( 4 )}$ Transparency & 1.14 & 1.07 & 0.876 & 0.124 \\
$\mathbf{( 5 )}$ & Foreign aid & 1.34 & 1.16 & 0.744 & 0.256 \\
$\mathbf{( 6 )}$ & Trade openness & 1.38 & 1.18 & 0.723 & 0.277 \\
$\mathbf{( 7 )}$ & Government savings & 1.27 & 1.13 & 0.787 & 0.213 \\
$\mathbf{( 8 )}$ & Gross Domestic Product (GDP) & 10.27 & 3.20 & 0.097 & 0.903 \\
& Mean VIF & $\mathbf{3 . 6 0}$ & & &
\end{tabular}

\begin{tabular}{|c|c|c|}
\hline \multicolumn{2}{|c|}{ Eigenval } & \multirow{2}{*}{$\begin{array}{r}\text { Condition Index } \\
1.000\end{array}$} \\
\hline 1 & 6.461 & \\
\hline 2 & 1.654 & 1.968 \\
\hline 3 & 0.496 & 3.584 \\
\hline 4 & 0.179 & 5.985 \\
\hline 5 & 0.124 & 7.229 \\
\hline 6 & 0.042 & 10.195 \\
\hline 7 & 0.025 & 16.065 \\
\hline 8 & 0.016 & 19.831 \\
\hline 9 & 0.004 & 41.177 \\
\hline \multicolumn{2}{|c|}{$\begin{array}{l}\text { Condition Number } \\
\text { Eigenvalues \& Cond } \\
\text { Index computed from } \\
\text { scaled raw sscp (w/ } \\
\text { intercept) }\end{array}$} & 40.592 \\
\hline & atrix) & 0.034 \\
\hline
\end{tabular}




\section{Figures}

Figure 1 Research model

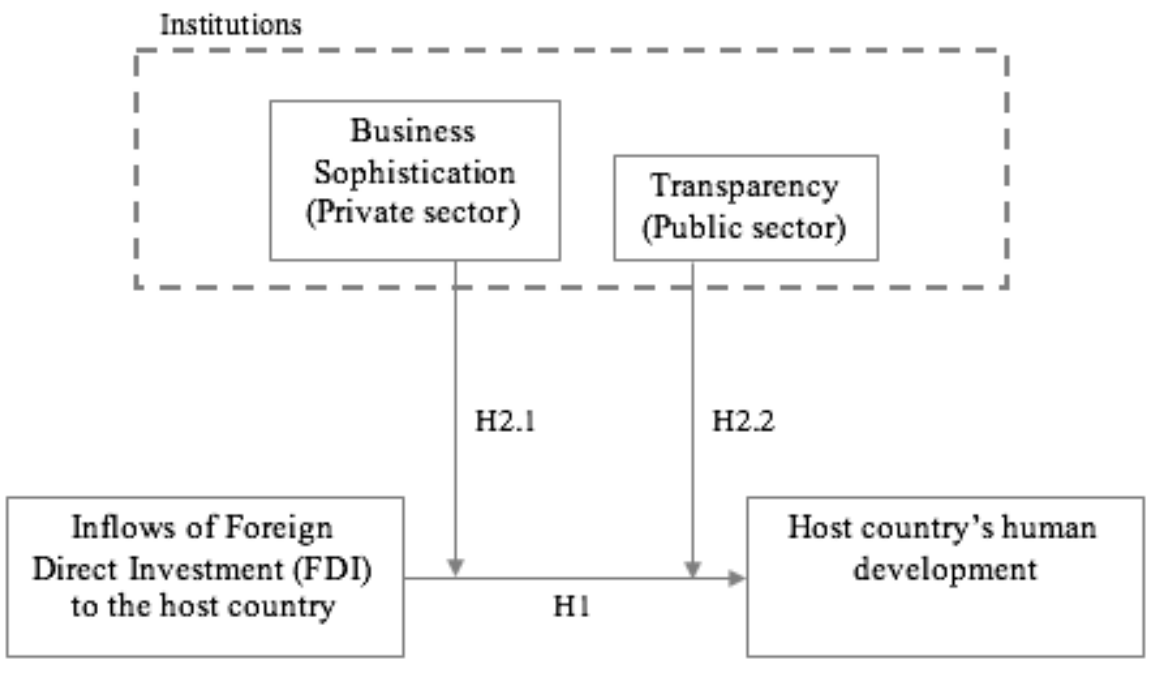


Figure 2 Interaction effect of business sophistication and Inward FDI stock on host country's human development (adjusted for effects of control variables)

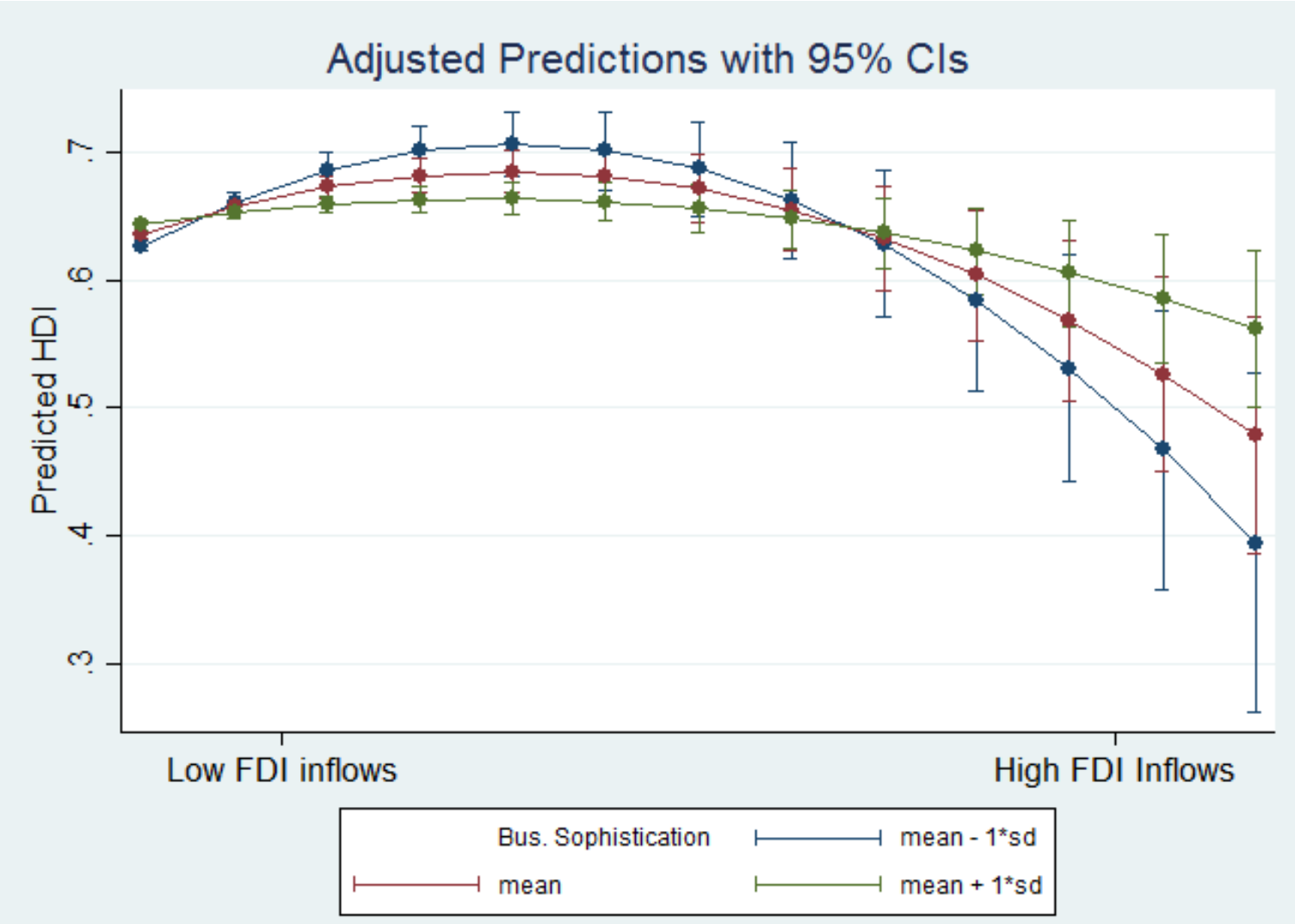


Figure 3 Interaction effect of transparency and Inward FDI stock on host country's human development (adjusted for effects of control variables)

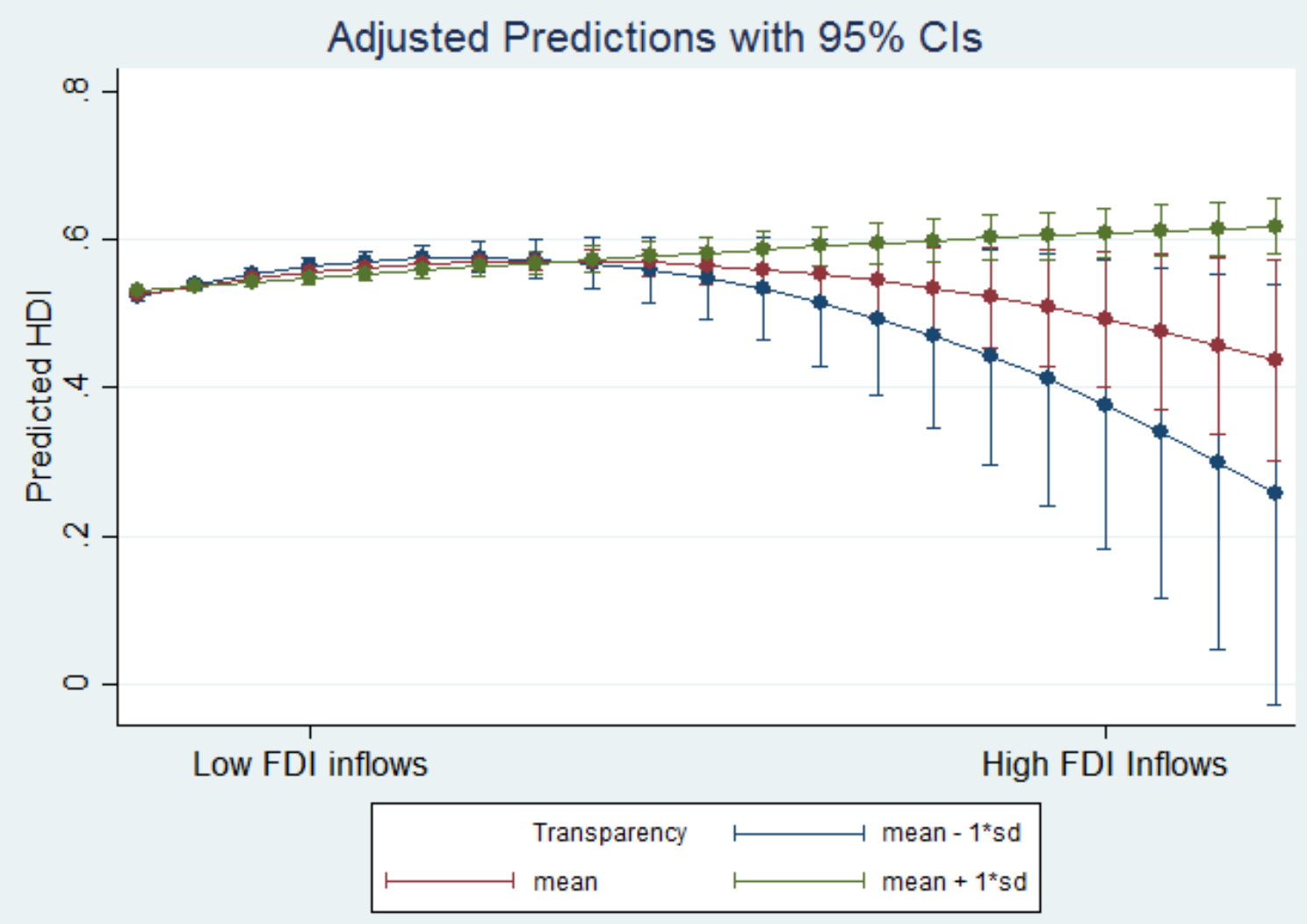




\section{APPENDIX}

\section{Appendix 1: Measurement scale of business sophistication}

Indicator

Local supplier quantity

Local supplier quality

State of cluster development

Nature of competitive advantage

Production process sophistication

Value chain breadth

\section{Question}

Answer options

In your country, how numerous are $1=$ largely non-existent; 7 local suppliers?

$=$ extremely numerous

In your country, how would you assess the quality of local suppliers?

In your country, how widespread are well-developed and deep clusters (geographic concentrations of firms, suppliers, producers of related products and services, and specialized institutions in a particular field)?

Upon what is the competitive advantage of your country's companies in international markets based?

In your country, how sophisticated are production processes?
$1=$ extremely poor quality; $7=$ extremely high quality

$1=$ non-existent; $7=$ widespread in many fields
$1=$ low-cost labor or natural resources; $7=$ unique products and processes

$1=$ not at all - production uses labor-intensive processes or old technology; 7 = highlyproduction uses sophisticated and knowledge-intensive processes

$1=$ narrow, primarily involved in individual steps of the value chain (e.g., resource extraction or production); $7=$ broad, present across the entire 
value chain (e.g.,

including production and marketing, distribution, design, etc.)

\author{
Control of international \\ distribution
}

Extent of marketing

Willingness to delegate authority
To what extent are international distribution and marketing from your country owned and controlled by domestic companies?

In your country, to what extent do companies use sophisticated marketing tools and techniques?

In your country, how do you assess the willingness to delegate authority to subordinates?
$1=$ not at all-they take place through foreign companies; 7 = to a great extent - they are primarily owned and controlled by domestic companies

$1=$ not at all; $7=$ to $a$ great extent

$1=$ not willing at allsenior management takes all important decisions; 7 = very willing - authority is mostly delegated to business unit heads and other lower level managers 
Appendix 2: List of the countries included on the sample

$\begin{aligned} 1 & \text { Afghanistan } \\ 2 & \text { Albania } \\ 3 & \text { Algeria } \\ 4 & \text { Angola } \\ 5 & \text { Antigua and Barbuda } \\ 6 & \text { Argentina } \\ 7 & \text { Armenia } \\ 8 & \text { Azerbaijan } \\ 9 & \text { Bahamas } \\ 10 & \text { Bahrain } \\ 11 & \text { Bangladesh } \\ 12 & \text { Barbados } \\ 13 & \text { Belarus } \\ 14 & \text { Belize } \\ 15 & \text { Benin } \\ 16 & \text { Bhutan } \\ 17 & \text { Bolivia } \\ 18 & \text { Bosnia and Herzegovina } \\ 19 & \text { Botswana } \\ 20 & \text { Brazil } \\ 21 & \text { Bulgaria } \\ 22 & \text { Burkina Faso } \\ 23 & \text { Burundi } \\ 24 & \text { Cambodia } \\ 25 & \text { Cameroon } \\ 26 & \text { Central African Republic } \\ 27 & \text { Chile } \\ 28 & \text { China } \\ 29 & \text { Colombia } \\ 30 & \text { Comoros } \\ 31 & \text { Congo } \\ 32 & \text { Congo, Dem. Rep. } \\ 33 & \text { Costa Rica } \\ 34 & \text { Cote d'Ivoire } \\ 35 & \text { Croatia } \\ 36 & \text { Cyprus } \\ & \end{aligned}$

37 Czech Republic

38 Denmark

39 Dominican Republic

40 Ecuador

41 Egypt

42 El Salvador

43 Equatorial Guinea

44 Estonia

45 Ethiopia

46 Gabon

47 Gambia

48 Georgia

49 Ghana

50 Grenada

51 Guatemala

52 Guinea

53 Guinea-Bissau

54 Guyana

55 Haiti

56 Honduras

57 Hungary

58 India

59 Indonesia

60 Iran

61 Iraq

62 Israel

63 Jamaica

64 Jordan

65 Kazakhstan

66 Kenya

67 Kuwait

68 Kyrgyzstan

69 Latvia

70 Lebanon

71 Lesotho

72 Libya 


\begin{tabular}{rlll}
73 & Lithuania & 109 & Saudi Arabia \\
74 & Macedonia, FYR & 110 & Senegal \\
75 & Madagascar & 111 & Serbia \\
76 & Malawi & 112 & Seychelles \\
77 & Malaysia & 113 & Sierra Leone \\
78 & Maldives & 114 & Singapore \\
79 & Mali & 115 & Slovenia \\
80 & Malta & 116 & Solomon Islands \\
81 & Mauritania & 117 & South Africa \\
82 & Mauritius & 118 & South Korea \\
83 & Mexico & 119 & Sri Lanka \\
84 & Moldova & 120 & Sudan \\
85 & Mongolia & 121 & Swaziland \\
86 & Montenegro & 122 & Syria \\
87 & Morocco & 123 & Tajikistan \\
88 & Mozambique & 124 & Tanzania \\
89 & Namibia & 125 & Thailand \\
90 & Nepal & 126 & Togo \\
91 & Nicaragua & 127 & Trinidad and Tobago \\
92 & Niger & 128 & Tunisia \\
93 & Nigeria & 129 & Turkey \\
94 & Oman & 130 & Uganda \\
95 & Pakistan & 131 & Ukraine \\
96 & Panama & 132 & United Arab Emirates \\
97 & Papua New Guinea & 133 & Uruguay \\
98 & Paraguay & 134 & Uzbekistan \\
99 & Peru & 135 & Venezuela \\
100 & Philippines & 136 & Vietnam \\
101 & Poland & 137 & Yemen \\
102 & Qatar & 138 & Zambia \\
103 & Romania & 139 & Zimbabwe \\
104 & Russia & & \\
105 & Rwanda & & \\
106 & Saint Kitts and Nevis & & \\
107 & Saint Lucia & & \\
108 & Saint Vincent and the Grenadines & & \\
& & & \\
\hline & & \\
9 & & \\
9 & &
\end{tabular}




\section{Appendix 3: Moderation matrix - Business Sophistication and Transparency}

\begin{tabular}{|c|c|c|}
\hline & Low FDI & High FDI \\
\hline $\begin{array}{l}\text { Sophisticated } \\
\underline{\text { Economies }}\end{array}$ & $\begin{array}{l}\text { MNEs are less able to be active } \\
\text { participants in the economy, and the host } \\
\text { country will probably gain modest } \\
\text { benefits, since it has achieved a certain } \\
\text { level of economic development in its } \\
\text { practices, strategies, and markets, and } \\
\text { independence from foreign businesses }\end{array}$ & $\begin{array}{l}\text { MNEs are more likely to undertake a } \\
\text { different role and shape the economy in } \\
\text { which they acquire power and leverage } \\
\text { in the host country. MNEs may influence } \\
\text { these markets and take advantage of } \\
\text { higher margins; this can generate lower } \\
\text { government income and decrease } \\
\text { workforce costs. MNEs pay minimal } \\
\text { resources to their countries of } \\
\text { investment, but substantially extract } \\
\text { from these countries to increase their } \\
\text { own profits; this translates to decreased } \\
\text { human development. These different } \\
\text { negative forces thus curtail the host } \\
\text { country's resources for individuals and } \\
\text { government, leading to rising income } \\
\text { inequality and scant increases in } \\
\text { government revenue, which significantly } \\
\text { diminishes human development. }\end{array}$ \\
\hline $\begin{array}{l}\text { Less } \\
\text { sophisticated } \\
\underline{\text { economies }}\end{array}$ & $\begin{array}{l}\text { These investments inject capital to } \\
\text { advance business practice, which in turn } \\
\text { generates more employment and } \\
\text { increases workforce participation. } \\
\text { Alongside this, foreign investments are } \\
\text { more likely to provide higher revenue to } \\
\text { governments and encourage the } \\
\text { development of educational systems that } \\
\text { support these industries; they also help } \\
\text { enhance educational attainment and } \\
\text { build human capital, which are key } \\
\text { elements of economic growth }\end{array}$ & $\begin{array}{l}\text { MNEs' investment increases, the costs } \\
\text { of this will most probably also rise. In } \\
\text { this context, such capital shapes the } \\
\text { economy and the role of foreign firms } \\
\text { in the host country as a market maker, } \\
\text { and MNEs then tend to have higher } \\
\text { leverage and control over domestic } \\
\text { firms, government, and local economy. } \\
\text { Therefore, as a consequence of } \\
\text { building the market, MNEs are feasibly } \\
\text { able to negotiate reduced tax rates } \\
\text { and favorable transactions that allow } \\
\text { them to improve their profit margins. } \\
\text { In addition, MNEs are more likely to } \\
\text { offer high wages only to specific parts } \\
\text { of the workforce (i.e., executives) who } \\
\text { may be in short supply, and pay } \\
\text { relatively low wages to the bulk of the } \\
\text { workforce to drive down costs. MNEs } \\
\text { thus create a gap between skilled and } \\
\text { unskilled employees' income, } \\
\text { minimizing incidental investment in } \\
\text { education, training, and upgrading } \\
\text { skills. }\end{array}$ \\
\hline $\begin{array}{l}\text { Economies with } \\
\text { high transparency }\end{array}$ & $\begin{array}{l}\text { New foreign entrants are unlikely to } \\
\text { contribute as much to the development } \\
\text { of the public sector; these economies }\end{array}$ & $\begin{array}{l}\text { MNEs are less able to gain leverage and } \\
\text { control over public policies, processes, } \\
\text { and practice. Specifically, governments }\end{array}$ \\
\hline
\end{tabular}




\begin{tabular}{|l|l|l|}
\hline & $\begin{array}{l}\text { might achieve standardized clear and } \\
\text { transparent policies, procedures, public- } \\
\text { sector employee roles. Thus, when FDI } \\
\text { has minimal effects on a host economy, } \\
\text { the human development benefits are also } \\
\text { smaller. }\end{array}$ & $\begin{array}{l}\text { in these economies are liable to be } \\
\text { accountable for their actions and possess } \\
\text { firm, transparent policies; foreign } \\
\text { companies will thus experience a well- } \\
\text { regulated public sector. MNEs might } \\
\text { find it difficult to gain advantage and } \\
\text { leverage over resources and funds. } \\
\text { Therefore, the costs associated with the } \\
\text { effects of FDI on the host country's } \\
\text { public sector and, more importantly, }\end{array}$ \\
\hline$\underline{\text { Economies with }}$ & $\begin{array}{l}\text { FDI's negative consequences on human } \\
\text { development are non-significant. }\end{array}$ \\
$\begin{array}{l}\text { MNEs are particularly helpful for } \\
\text { developing the institutional environment } \\
\text { in such a way that foreign business may } \\
\text { positively influence the host country's } \\
\text { policies and procedures, and be more } \\
\text { likely to exercise regulatory and } \\
\text { demonstration effects on the host } \\
\text { country's public institutions. These } \\
\text { effects put pressure on public institutions } \\
\text { to restructure at a more global level, thus } \\
\text { enabling them to gain legitimacy and } \\
\text { enact clear and transparent policies and } \\
\text { practices. }\end{array}$ & $\begin{array}{l}\text { The costs of FDI are also likely to rise. } \\
\text { In this context, foreign capital might } \\
\text { acquire more leverage over public } \\
\text { practices and processes, which gives } \\
\text { MNEs more control over public-sector } \\
\text { funds. This increased leverage comes at } \\
\text { a cost, affecting both individuals and the } \\
\text { host country. Specifically, MNEs have } \\
\text { greater opportunity to extract resources } \\
\text { from the host country with little } \\
\text { accountability. }\end{array}$ \\
\hline
\end{tabular}

